Universidade de Brasília - UnB

Instituto de Psicologia - IP

Departamento de Psicologia Escolar e do desenvolvimento - PED

Programa de Pós-Graduação em Processos de desenvolvimento

Humano e Saúde - PGPDS

CURSO DE ESPECIALIZAÇÃO EM DESENVOLVIMENTO HUMANO, EDUCAÇÃO E INCLUSÃO ESCOLAR - UAB/UnB

\title{
ASPECTOS HISTÓRICOS DA SOCIALIZAÇÃO DE ALUNOS COM DEFICIÊNCIA INTELECTUAL NUMA ESCOLA DA REDE PÚBLICA MUNICIPAL DE ENSINO DE IPATINGA/MG
}

VERA LÚCIA ROQUE SANTOS

ANELICE DA SILVA BATISTA 


\section{VERA LÚCIA ROQUE SANTOS}

\section{ASPECTOS HISTÓRICOS DA SOCIALIZAÇÃO DE ALUNOS COM DEFICIÊNCIA INTELECTUAL NUMA ESCOLA DA REDE PÚBLICA MUNICIPAL DE ENSINO DE IPATINGA/MG}

Monografia apresentada à Universidade de Brasília para aprovação do curso de Pós-graduação em Processos de Desenvolvimento Humano e Saúde sob a orientação da professora Anelice da Silva Batista. 


\section{TERMO DE APROVAÇÃO}

VERA LÚCIA ROQUE SANTOS

\section{ASPECTOS HISTÓRICOS DA SOCIALIZACCÃO DE ALUNOS COM DEFICIÊNCIA INTELECTUAL NUMA ESCOLA DA REDE PÚBLICA MUNICIPAL DE ENSINO DE IPATINGA/MG}

Monografia aprovada como requisito parcial para obtenção do grau de Especialista do Curso de Especialização em Desenvolvimento Humano, Educação e Inclusão Escolar - UAB/UnB. Apresentação ocorrida em /2011.

Aprovada pela banca formada pelos professores

ANELICE DA SILVA BATISTA (Orientadora)

(Examinadora)

VERA LÚCIA ROQUE SANTOS 


\section{DEDICATÓRIA}

Dedico esse trabalho às crianças com as quais trabalhei. O aprendizado foi grandioso! E o intuito de buscar melhorias para esse público é fonte de motivação e dedicação. 


\section{AGRADECIMENTOS}

Agradeço a Deus por ter me permitido alcançar um estágio de minha formação acadêmica inimaginável há alguns anos atrás, e que Ele me permita ainda muito mais.

Aos familiares, que auxiliaram e entenderam muitas vezes os meus vários momentos de "não": Não posso ir... Não tenho tempo para... Não vou chegar a tempo de...

Aos tutores do Curso de Especialização em Desenvolvimento Humano, Educação e Inclusão, pela incansável dedicação e apoio.

Agradeço em especial a professora orientadora Anelice da Silva Batista, pela dedicação, disposição e compreensão com que sempre me atendeu.

Agradeço com especial atenção meus filhos: Alan, Gustavo e Tamir e ao meu esposo, Geraldo, pela dedicação com que sempre estiveram ao meu lado, me auxiliando em todos os momentos.

Agradeço ainda às crianças, pais e professores que participaram comigo neste trabalho, contribuindo para sua realização.

"É preciso descobrir nosso jeito de Ser e Intervir no mundo. Desse modo, todos são importantes e imprescindíveis. Não mais e nem menos, nem melhores ou piores, tampouco perdedores ou vencedores. Somos algo além dessas fragmentações e polarizações, somos "inteiros e não pela metade"!" (Fabio Brotto)

"Pouco conhecimento faz com que as criaturas se tornem orgulhosas. Muito conhecimento, que se tornem humildes!'. Leonardo Da Vinci (1452 - 1519). 


\section{RESUMO}

Os aspectos históricos da socialização de alunos com deficiência intelectual na rede pública municipal de ensino de Ipatinga/MG não difere dos demais lugares. Este trabalho tem como objetivo diagnosticar e identificar os aspectos históricos da socialização presentes na escola e família que influenciam a inclusão dos alunos com necessidade educacional especial (NEE), bem como mostrar o atraso, quase sempre ocorrido com alunos com NEE, no que diz respeito aos aspectos da socialização. Num contexto, em que culturas e pessoas distantes ou desconhecidas podem ser acessadas e descobertas por um click na tecla do computador, faz-se necessária uma visão de mundo na qual não existam fronteiras apenas entre as nações e os povos, mas também entre as pessoas próximas, principalmente as estigmatizadas e excluídas por marcas físicas e/ou sociais. A proposta de inclusão de pessoas portadoras de deficiências sensoriais, físicas e mentais ou de impedimentos construídos socialmente, que servem para explicar a incapacidade que certos grupos ou indivíduos têm de ascensão intelectual e/ou social nos diversos espaços sociais, não surgiu de repente. Ela vem sendo construída ao longo de vários anos e ainda permanece nos dias de hoje, atrasando de forma significativa o desenvolvimento de pessoas. Através de estudo de várias teorias que tratam sobre o assunto, principalmente a de Vygostsky, e através de pesquisa com alunos, pais e professores, foi possível concluir que apesar da dificuldade de aprendizagem inerente à eles, o atraso maior no desenvolvimento dos alunos em questão, no que diz respeito à socialização, se devem ao fato destes serem privados a princípio da convivência social com pretexto de não sem machucarem ou outros temores da própria família, com relação a aceitação tanto por ela quanto pelas outras pessoas ou mesmo de super proteção. A socialização acontece quando participamos da vida em sociedade, assimilando todas as suas principais características. Tendo por definição que quanto mais coerente for a socialização, mais sociável ele tenderá a ser. Portanto, privar o ser humano da convivência com os seus é dificultar seu desenvolvimento e colaborar para o seu fracasso.

Palavras-chaves: Socialização; Educação Inclusiva; Deficiência Intelectual. 


\section{SUMÁRIO}

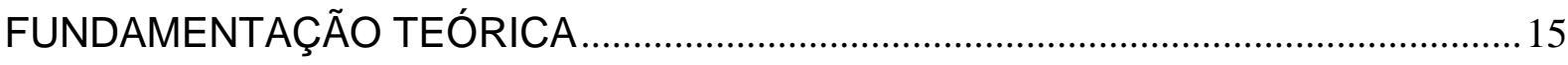

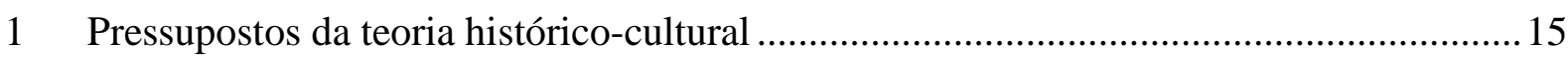

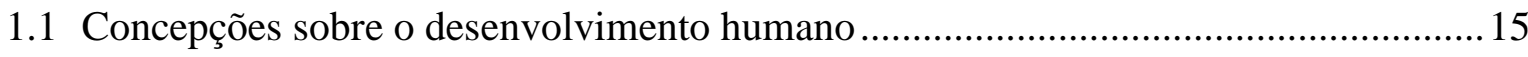

1.2 Concepção histórico-cultural da deficiência intelectual ............................................. 17

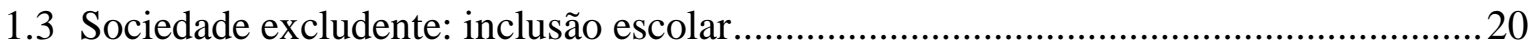

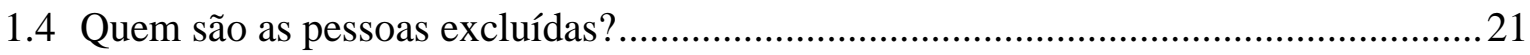

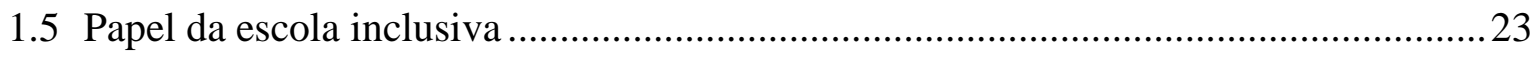

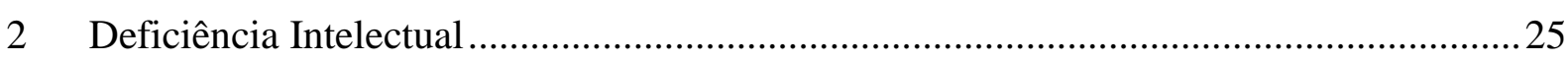

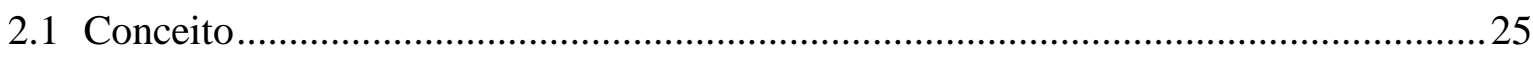

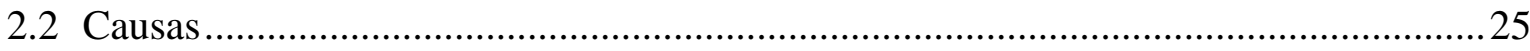

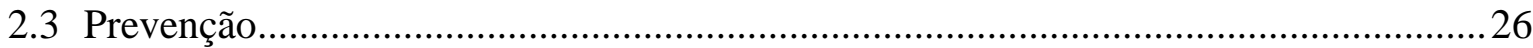

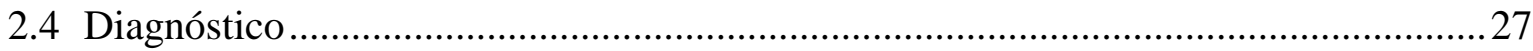

3 Educação Especial no Município de Ipatinga...................................................................29

3.1 Atendimento da Educação Especial em Ipatinga .......................................................2 29

3.2 Objetivos do atendimento da Educação Especial em Ipatinga .....................................2 29

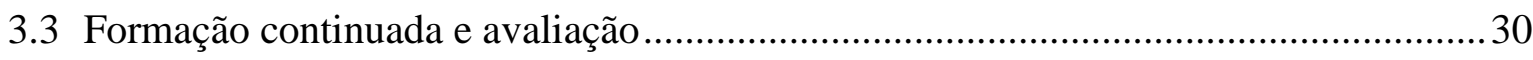

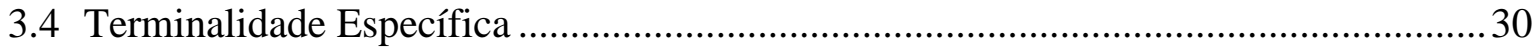

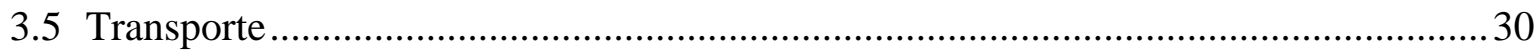

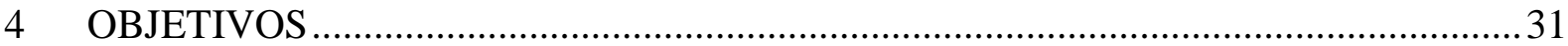

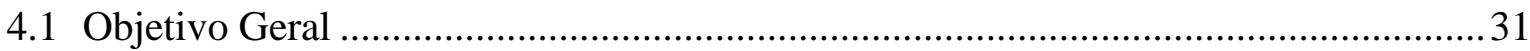

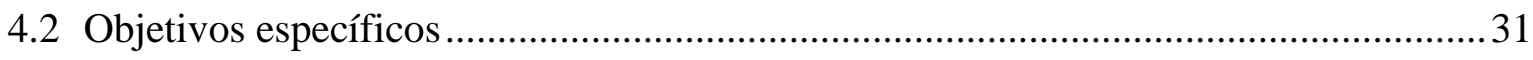

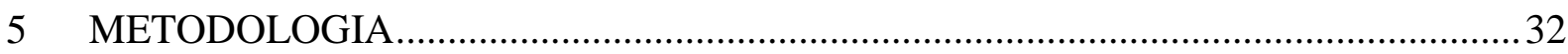

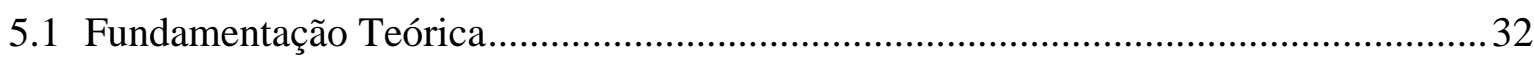

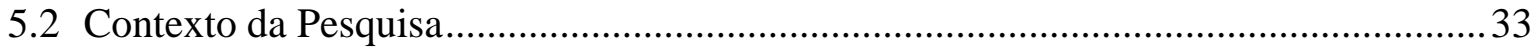

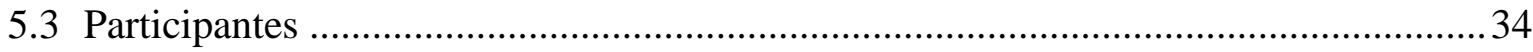

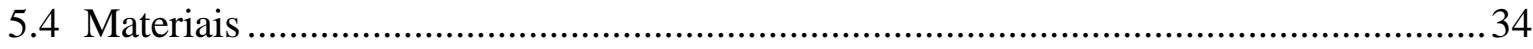

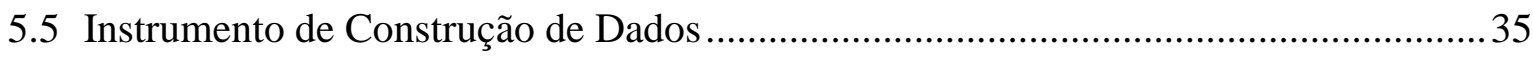

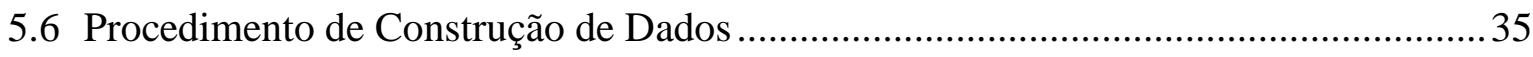

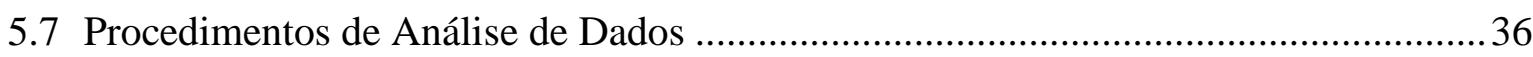

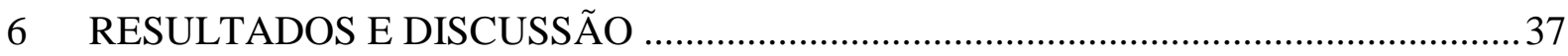

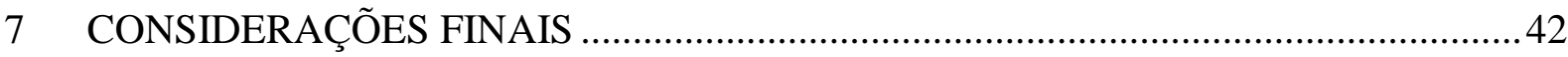

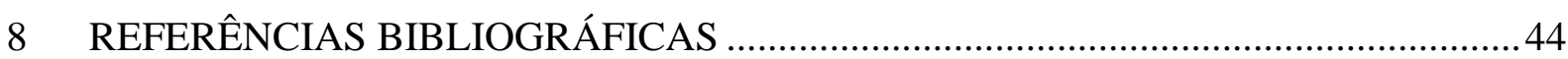


Apêndice A - Questionário 1 (Entrevista com profissionais da escola) ................................ 48

Apêndice B - Questionário 2 (Entrevista com a família).................................................... 49

Apêndice C - Questionário 3 (Entrevista com os alunos) ..................................................50

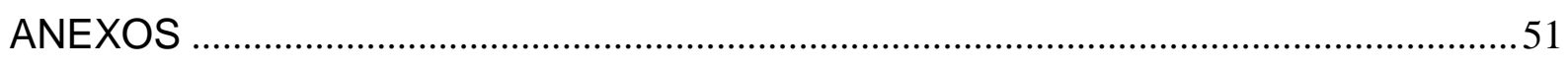

Anexo A - Carta de apresentação à Instituição ..................................................................52

Anexo B - Termo de Consentimento Livre e Esclarecido ....................................................53

Anexo C - Resolução Sobre a Educação de Alunos com NEE ..............................................54 


\section{LISTA DE QUADROS, TABELAS OU GRÁFICOS}

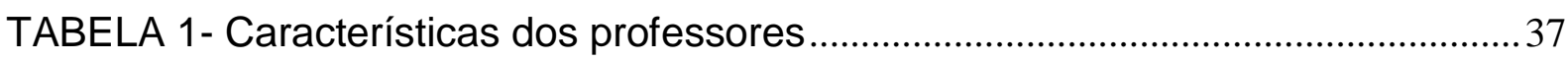

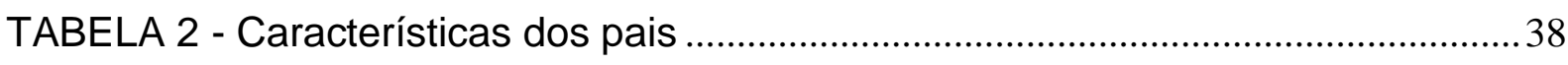

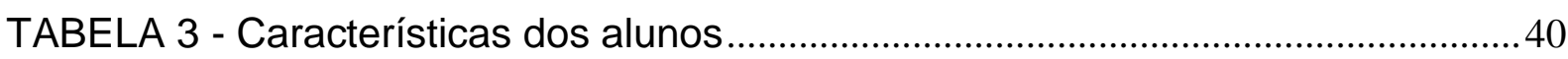




\section{APRESENTAÇÃO}

As reflexões contidas nesse trabalho monográfico têm por objetivo compreender de forma breve, porém sistemática, de que maneira se dá a socialização de alunos com deficiência intelectual numa escola da rede pública de ensino da cidade de Ipatinga/MG. Há uma vasta legislação especifica sobre inclusão de pessoas com necessidades educacionais especiais, porém percebe-se as dificuldades para efetivação dessa proposta. Sabe-se que para efetivar uma inclusão de fato na rede pública de ensino, não basta simplesmente o cumprimento da lei, matriculando a pessoa com NEE.

Para ultrapassar as barreiras de implementação da educação inclusiva talvez seja necessário construir um novo modelo educacional. As escolas precisam abandonar velhas práticas e se abrirem para o novo, desencadeando ações que possam centralizar seu Projeto Político Pedagógico para a diversidade. Se as escolas focarem nas diferenças, incrementam a exclusão e não a inclusão.

A partir da visão dos direitos humanos e do conceito de cidadania fundamentado no reconhecimento das diferenças e na participação dos sujeitos, decorre uma identificação dos mecanismos e processos de hierarquização que operam na regulação e na produção das desigualdades. Essa problematização explicita os processos normativos de distinção dos alunos em razão de características intelectuais, físicas, culturais, sociais e lingüísticas, entre outras, estruturantes do modelo tradicional de educação escolar.

Sou professora há 22 anos das séries iniciais e interesso-me pelos projetos que a rede de ensino implementa com o objetivo de auxiliar as crianças com dificuldades de aprendizagem. Busco, constantemente, respostas para as dificuldades de aprendizagem que sempre são atribuídas à elas, levando à rotulação e à estigmatização das crianças desde o começo da vida escolar.

Dessa forma, autores expõe sobre a inclusão, baseando-se, conforme Gomes e Silva (2005, p.40), da seguinte maneira:

a inclusão escolar de alunos com deficiências [...] no sistema regular de ensino, está assentada, no direito que toda criança tem à educação, fundamentado no Princípio da Inclusão e na Ética da Diversidade. A nova Lei de Diretrizes e Bases da educação, Lei № 9.394 de dezembro de 1996, avança nestes aspectos, mas ainda não se faz cumprir de fato no chão da escola. Para isso, é fundamental que o educador se alimente de discussões teóricas e conceituais que possam fundamentar uma prática pedagógica 
que esteja de acordo com essas exigências, para se adequar o mais rápido possível, pondo em prática este discurso e favorecendo enfim está inclusão".

Em assuntos complementares, chegava-se à interpretações sobre o desenvolvimento.Vygotsky pensava que

\begin{abstract}
o sujeito humano é social desde o momento em que nasce. Porque ele está imerso, desde seus primeiros dias de vida, em um contexto social, a formação dos processos cognitivos é decorrente, portanto, de uma mente social. Ao falar sobre a natureza social do psiquismo humano, ele ressalta que as capacidades humanas são formadas a partir das interações sociais. Foi então que Vygotsky estabeleceu a Lei Genética Geral do Desenvolvimento Cultural, que afirma: Toda função no desenvolvimento cultural da criança aparece em cena duas vezes, em dois planos; primeiro no plano social e depois no psicológico, a princípio entre os homens como categoria interpsíquica e logo no interior da criança como categoria intrapsíquica (GOMES e SILVA 2005, p.150).
\end{abstract}

Para Ford e Lerner (1992), desenvolvimento humano, de maneira abrangente, é entendido como uma conotação, de modo que o irá implicar em transformações sucessivas e permanentes, sistêmica, em que múltiplos fatores influenciam.

Além desse contexto do desenvolvimento, o que também leva à forma de socializar,

\begin{abstract}
o modelo educacional brasileiro ao mesmo tempo em que lança seus pilares no princípio da igualdade entre os homens, comete alguns equívocos no que diz respeito ao fato de agrupar os alunos em classes homogêneas e, por meio da aferição quantitativa de desempenho, tornar explícitas as desigualdades e diferenças num processo em que todos os alunos são submetidos aos mesmos instrumentos de avaliação. (CARMO, 2001. p. 25)
\end{abstract}

Desse modo, "a ênfase no padrão de normalidade é, todavia, o critério para a adoção de medidas excludentes, legitimadas por instrumentos de avaliação que quase nada têm a informar sobre o verdadeiro potencial dos sujeitos [...]". (VIGOTSKI, 1995. p. 43)

O processo de socialização inicia-se, contudo, após o nascimento, e através, primeiramente, da família ou outros agentes próximos, da escola, dos meios de comunicação de massas e dos grupos de referência que são compostos pelas nossas bandas favoritas, atores, atletas, super-heróis. A socialização é o processo, através do qual o indivíduo se integra, no grupo em que nasceu, adquirindo os seus hábitos e valores característicos.

É através da socialização que o indivíduo pode desenvolver a sua personalidade e ser admitido na sociedade. $\mathrm{O}$ aluno intitulado deficiente participa de 
todos os projetos criados pela escola ou Secretaria de Educação que procuram diminuir a diferença, sem, contudo avançar no sentido de garantir sua socialização durante anos e anos.

No cotidiano escolar, é possível observar sempre os alunos rotulados por colegas como alunos com dificuldades de aprendizagem. A escola atende do segundo ano do primeiro ciclo até o nono ano do quarto ciclo. Isso torna possível acompanhar do início ao fim sua trajetória escolar, ou seja, enquanto permanece no Ensino Fundamental.

No início do processo de escolarização, ou seja, na admissão deste aluno, só o professor é capaz de identificá-lo como aluno (a) com problemas de aprendizagem. Meses depois toda classe já o identifica como aluno/problema, pois basta você visitar e pedir para executar qualquer tarefa, os próprios colegas já informa de sua incapacidade ilustrada bem nas falas: "Ele não sabe nada, ele não faz nada." Com o passar dos anos a escola, em toda sua abrangência, já é capaz de identificá-lo como tal. É percebido que, o aluno ao ingressar na escola no início de sua vida escolar ainda ele ou seus colegas não vêem motivos para tratamentos diferenciados, se portando de forma alegre, descontraída interage com todos.

A diversidade humana ainda não constitui para ele ou os demais colegas como obstáculo ao convívio social. Até o final do Ensino Fundamental I ele é alvo de muito investimento, mas também de muita exposição. Quando entra no Ensino Fundamental II (6ำ ao 9a ano) ou com passar dos anos, ele tenta se camuflar e muitas vezes passa despercebido, se torna mais introspectivo, às vezes triste e com poucos colegas, às vezes rebelde.

Tanto um quanto outro papel que desempenha nada mais é que o retrato de seu fracasso, agora estampado no seu rosto e publicado na escola através das falas e apontamentos dos colegas e de seus professores.

Tantos fatores influenciam no desenvolvimento, e nada menos no que se diz respeito à cultura. Esta,por sua vez, vem sendo estudada por diferentes áreas do conhecimento e pode ser conceitualizada conforme a perspectiva que se assuma: antropológica, arqueológica, psicológica (evolutiva, social, desenvolvimental, transcultural, por exemplo) ou sociológica. "Ela cria formas especiais de comportamento e se baseia no centro do desenvolvimento das funções psicológicas humanas". (VYGOTSKY, 1987) Raciocínio verbal, formação de conceitos, atenção voluntária e memória lógica são alguns exemplos dessas funções psicológicas 
superiores mediadas pela cultura. O processo de desenvolvimento é organizado pela permanente construção e reconstrução de limites em nosso comportamento, nos mais variados contextos. Os fenômenos psicológicos complexos são influenciados por esses limites culturais e, ao mesmo tempo, influenciam a cultura.

E por não ocupar posições semelhantes em todos os espaços sociais, cada vez mais o contato precoce com outros universos além da família está presente em nossas vidas ou em que a criança e o jovem são levados a conviver, apresentam-se situações heterogêneas, concorrentes e às vezes contraditórias, no que se refere aos princípios da socialização.

Dessa forma, a socialização, mesmo acontecendo durante toda a vida, dá-se com intensidades e em contextos diferentes.

A socialização primária acontece com grande identificação emocional do indivíduo com os valores transmitidos pelos pais. Durante a infância, ocorre à socialização primária, onde a criança aprende e interioriza a linguagem, as regras básicas da sociedade, a moral e os modelos comportamentais do grupo a que se pertence. Esta se mostra com um valor primordial para o indivíduo e deixa marcas muito profundas em toda a sua vida, já que é aí que se constrói o primeiro mundo do indivíduo. (na escola, nos grupos de amigos, no trabalho, nas atividades dos países que visitamos ou para onde emigramos), existindo uma aprendizagem das expectativas que a sociedade ou o grupo depositam nos indivíduos.

$\mathrm{Na}$ socialização secundária a identificação acontece somente na medida necessária para a comunicação entre os seres humanos, podendo, os conhecimentos serem adquiridos numa seqüência de aprendizagem e reforçados por técnicas pedagógicas específicas. Resume-se num processo subseqüente que introduz um indivíduo já socializado em novos sectores do mundo objetivo da sua sociedade "eu" como o centro de tudo. Cabe ressaltar a importância sobre o que forma o caráter humano nos indivíduos da espécie humana é a convivência. A extensão e o caráter da socialização secundária são determinados pela complexidade da divisão do trabalho e concomitantemente, pela distribuição social do conhecimento de uma dada sociedade.

Partindo do pressuposto de que a socialização é fundamental para o desenvolvimento de qualquer ser humano, seguem os títulos conforme proposta anteriormente descrita.

Para finalizar, é importante salientar que essa circulação e a intensidade 
de penetração de novas formas de pensar e agir, em outras palavras, a circularidade de novas maneiras de conceber e interpretar o mundo, será sempre apropriadas e experimentadas de forma particular e singular, pois estão continuamente sujeitas aos condicionamentos sociais e às trajetórias individuais ou de grupos. Não se trata de um processo homogêneo e massificado. Trata-se sempre de experiências individuais que se apropriam da heterogeneidade e da complexidade do mundo social a partir de um repertório conquistado a priori e um devir construído no presente. 


\section{FUNDAMENTAÇÃO TEÓRICA}

\section{Pressupostos da teoria histórico-cultural}

"Estar informado e atento é o melhor jeito de ajudar a construir a sociedade que queremos, ainda que sem ações espetaculares"

(Lya Luft, Veja, 3/3/2010)

\subsection{Concepções sobre o desenvolvimento humano}

No início do século XX, Lev Seminovich Vigotski (1989, 1993, 1994 e 2000) se destaca no cenário acadêmico russo apresentando, por meio de seus estudos e pesquisas em psicologia, uma nova concepção sobre o desenvolvimento humano (que ele denominará de ontogênese). Para os autores dessa abordagem teórica, nós somos constituídos a partir das relações que mantemos com outras pessoas. A forma como pensamos, sentimos e agimos sobre o mundo está relacionada com as condições sociais que nos são ofertadas pela cultura (daí advém à importância da escola). Tornar-se pessoa é participar ativamente das dinâmicas sociais que nos circunscrevem e nos constituem. O que somos depende da forma como as pessoas se posicionam na relação que mantém conosco. Dessa forma, quanto mais rica, múltipla e produtiva forem nossas interações sociais, mais potencializadas serão nossas dimensões subjetivas.

O autor concebe a ontogênese vinculada ao processo sócio-histórico em que o sujeito se insere e às dinâmicas culturais que ele (com) partilha desde o momento em que nasce. Ao traçar uma rápida consideração sobre Ontogênese e Filogênese, é possível perceber que, para Vigotski e seus colaboradores, as questões ontogenéticas, que dizem respeito ao desenvolvimento individual de uma pessoa, relacionam-se intimamente a aspectos do desenvolvimento filogenético, ou seja, a aspectos do desenvolvimento de nossa espécie, ao largo da história da humanidade, sob influência direta das transformações sócio-históricas vivenciadas por nossos ancestrais. O exemplo mais importante na sua obra, em relação a esses conceitos, diz respeito ao desenvolvimento da linguagem. 
Se do ponto de vista filogenético a linguagem é o centro das diferenças substanciais entre o homem e os animais, por constituir o fundamento para o funcionamento das funções psíquico-superiores, no âmbito ontogenético, sua centralidade está também evidenciada. Todas as ações humanas são recortadas, significadas e guiadas pela palavra. Desde o nascimento, nas suas relações com os adultos, a criança tem o seu universo recortado; as coisas vão sendo nomeadas e, paulatinamente, ela vai se integrando a rede de significados historicamente produzidos. Vigotski (1994) explica que, antes de dominar a palavra, a criança se encontra num período pré-intelectual da linguagem; ela age de forma prática em suas ações sobre o mundo e resolve problemas que não dependem de uma elaboração simbólica. Além disso, encontra-se numa fase pré-verbal do pensamento; ela chora, ri e apresenta manifestações verbais que indicam uma tentativa difusa de se comunicar com as pessoas que a cerca.

A criança já está imersa num ambiente linguístico e apresenta embrionariamente uma dimensão intelectiva e simbólica.

$\mathrm{Na}$ medida em que se apropria, paulatinamente, da palavra e começa a falar para organizar a sua ação no mundo, indicando as suas motivações para um interlocutor, a criança opera de outra forma, seu pensamento torna-se verbal e sua linguagem intelectual. Ela, então, começa a elaborar o significado das palavras. A partir daí, a linguagem e o pensamento seguem o mesmo curso e se interpenetram, ou seja, ela pensa em palavras e, ao utilizar as palavras, ativa o seu pensamento: a própria consciência.

A linguagem e o pensamento organizam o fundamento da atividade mental, que é geneticamente social. Nessa linha, o homem é concebido como um ser social e o desenvolvimento dos processos psicológicos superiores (imaginação, memória, percepção etc.) é dependente das relações que o sujeito estabelece com a história e a cultura de seu grupo social, por meio da palavra.

Desde o nascimento, nas suas relações com os adultos, a criança tem o seu universo recortado; as coisas vão sendo nomeadas e, paulatinamente, ela vai se integrando a rede de significados historicamente produzidos. A mãe, mesmo que a criança não entenda, conversa com seu bebê marcando o mundo pela diferenciação de objetos e suas funções. O riso da criança, que num primeiro momento é mera ação reflexiva do organismo, passa a ser significado pelo outro (PINO, 2005). 
O corpo do bebê e suas ações são nomeados pelo adulto que vai conferindo significado às atitudes da criança. Vigotski descreve que

\begin{abstract}
a ação da criança para agarrar um objeto, na maioria das vezes, é entendida pela mãe como a intenção do bebê de pegar algo. A mãe, então, passa a atribuir a essa ação um novo significado, transformando-a em gesto de apontar. A criança por sua vez, na medida em que toma para si essa nomeação (por meio de sua relação com a mãe e outros interlocutores), internaliza um modo de se posicionar no mundo, passando a apontar e indicar objetos que precisa ou deseja. Vigotski denominou a conversão da experiência social (experiência que se vive com os outros) em formas internas de funcionamento como processo de internalização. Esse processo de internalização inicia-se nas relações sociais, nas quais os adultos ou as crianças mais velhas, por meio da linguagem, do jogo, do 'fazer junto' ou do 'fazer para', compartilham com a criança seus sistemas de pensamento e ação. (FONTANA e CRUZ, 1997. p. 63)
\end{abstract}

De acordo com essa perspectiva teórica, o desenvolvimento humano se organiza em função dos intercâmbios sociais que estabelecemos com nossos pares, numa determinada cultura e em momento histórico específico. $O$ que as pessoas representam seus valores, crenças, sentimentos, formas de pensar, não são inatos, mas construídos pelas dinâmicas sociais que circunscrevem a experiência no mundo. Esse aspecto central da teoria proposta por Vigotski e seus principais colaboradores, revela o caráter mediador da constituição humana e marca a especificidade da forma consciente, dos indivíduos, de suas atuações no mundo. Ou seja, é a partir de outros homens, por meio da linguagem e dos instrumentos criados culturalmente, que nos constituímos como pessoa.

\title{
1.2 Concepção histórico-cultural da deficiência intelectual
}

A análise histórica sobre a deficiência intelectual expõe a variedade de crenças e concepções ligadas ao tratamento desses indivíduos. $\mathrm{Na}$ antiguidade clássica, fica explícito a predominância de uma visão mítica, sobrenatural do fenômeno, a que vão sobrepor, em épocas futuras, a visão naturalista e a social respectivamente. (TUNES, 2002)

A visão sobrenatural e a naturalista, contém um sentido de predestinação. A visão sobrenatural (não humana) entende a origem da deficiência, da imperfeição. Essa concepção retrata indivíduos, até então, fora da natureza, regida por forças sobrenaturais. A deficiência era vista como um castigo e instituída por esta força sobrenatural. Prova dessa idéia e concepção de alguns povos da antiguidade como 
o egípcio que ligava a causa da deficiência a maus espíritos, a pecados de vida passadas, para os gregos era um castigo ou vingança divina da mesma forma os romanos e para os hebreus a causa era pecado ou impureza do deficiente ou seus genitores. Para cada povo a visão da deficiência era tratada de uma forma, ligadas sempre à vontade de um Deus, que exigia desde preces e magias até o abandono e extermínio.

Já visão naturalista postula sua crença na origem biológica da deficiência, num erro da natureza, numa fatalidade, mesmo com o advento do cristianismo apesar do deficiente ganhar alma, ser considerado também filho de Deus, a visão da deficiência enquanto castigo perdura até os dias de hoje.

Após algum tempo muda-se o foco do causador da deficiência, antes a vontade divina ou sobrenatural. A visão passa para o entendimento que é o homem que se guia conforme seus interesses, criando assim a visão da poligenia, ou seja, as diversas raças seriam de origem de ancestrais diferentes. Portanto os deficientes seriam de uma raça específica ou uma espécie degenerativa. Outras formas de hierarquizar a raça humana são ligadas à quantificação da inteligência, predominante até bem pouco tempo.

Segundo Santos (2010) apud (ARANHA, 2001, p.211),

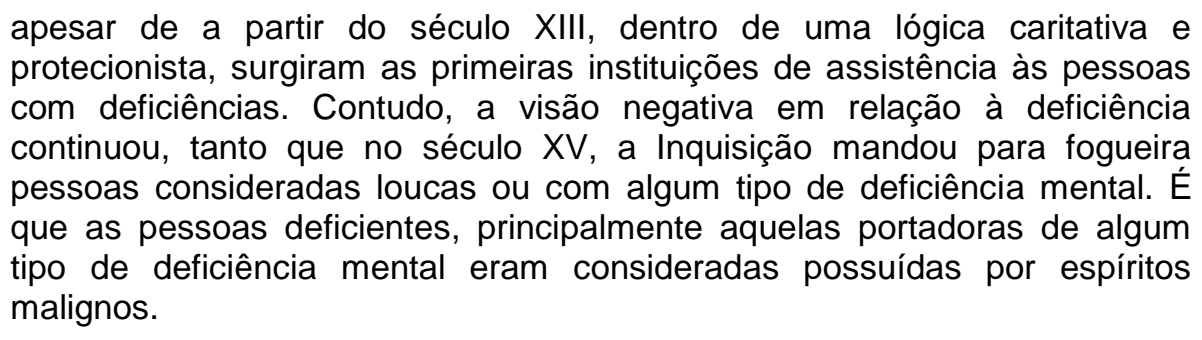

$\mathrm{Na}$ Idade Média, com a ascensão do Cristianismo e a confirmação da Igreja católica na sociedade, essa forma de exclusão passa ser contestada, uma vez que essas pessoas, segundo a visão da lgreja, também são possuidoras de alma. É nessa época que o panorama político começa mudar.

Várias concepções vão sendo embasadas e levando em consideração os documentos, congressos e estudos publicados no que tange o direito à educação, como por exemplo, considerando recentemente devido a história antiga da educação, em Salamanca (Espanha), no ano de 1994, ocorreu a Conferência Mundial sobre Necessidades Educacionais Especiais: Acesso e Qualidade. Desse evento, criou-se o documento "Declaração de Salamanca" no qual tratava sobre 
princípios, política e prática em educação especial, afirmando-se a urgência de ações para uma educação capaz de reconhecer as diferenças, promover a aprendizagem e atender às necessidades de cada criança individualmente.

Em outra visão, conforme a concepção social, ao longo da história, algumas diferenças entre os homens são selecionadas culturalmente, em função de algumas atividades humanas socialmente valorizadas. Dessa forma, a deficiência é uma espécie de sentimentos que emerge das relações particulares que se estabelece com essas pessoas. Para isso, seguindo essa linha de pensamento, o tratamento dispensado a essas pessoas deve incluir o contexto social em que elas vivem. Para esta concepção, mesmo que a característica seja biológica, esta incapacidade se dá por causa da condição social.

"Na concepção histórico-cultural as leis que regem o desenvolvimento humano tanto do ser normal como o deficiente, são as mesmas, assim como as que regem as atividades vitais dos seres humanos." (VYGOTSKY,1993)

Para melhor compreender os aspectos pertinentes ao desenvolvimento humano e sua intrínseca relação frente às condições culturais e relações sociais, um dos interesses de Vigotski foi estudar o desenvolvimento de crianças com deficiência num esforço de entender e analisar a constituição de seu funcionamento psíquico superior. A ênfase no estudo sobre sujeitos que possuem desenvolvimento atípico se justifica pelo desenvolvimento cultural excepcional, em função de específicas formas de interagir com a realidade, acarretando peculiaridades na construção do plano lingüístico e cognitivo.

Em seus textos publicados nos volumes de "Fundamentos de Defectologia" (1989), Vigotski tece considerações sobre o desenvolvimento mental das crianças deficientes. $O$ autor afirma que na ontogênese o desenvolvimento cultural transforma as possibilidades do organismo (biológico) formando um processo complexo, fato esse que, analisar apenas o aspecto biológico não permite explicar o que é específico ao homem, não revela o modo de funcionamento da atividade mental.

Diante a diversidade de concepções sobre deficiência, a visão sobrenatural e a naturalista atravessaram o tempo e mantém-se até hoje atualizadas, ainda que elas se oponham a visão eussêmica, que defende que a intervenção sobre o fenômeno da deficiência deve necessariamente abranger a comunicação coletiva, a colaboração e as relações que se estabelece entre a pessoa deficiente e as ditas normais. 
No novo cenário que se instaurou, mediante a educação e a partir da expansão do Cristianismo, foram se extinguindo formas de eliminação da pessoa deficiente, pois as mesmas são possuidoras de almas. Com isso podemos perceber que o fenômeno da inclusão não é, portanto novo. Há várias formas de inclusão que decorrem das diversas formas de concepções sobre deficiência. Resta-nos saber de qual estamos falando.

\subsection{Sociedade excludente: inclusão escolar}

Autores como Mrech (2005), descrevem sobre a inclusão escolar ou educação especial relatando que, a educação de "[...] uma escola inclusiva deve ser entendido como um processo social em que todas as crianças portadoras de necessidades especiais e de distúrbios de aprendizagem têm o direito à escolarização o mais próximo do normal."

A inclusão está fundada na dimensão humana e sociocultural que procura enfatizar formas de interação positivas, possibilidades, apoio às dificuldades e acolhimento da necessidade dessas pessoas, tendo como ponto de partida a escuta dos alunos, pais e comunidade escolar. (BRUNO, 2006. p.11)

A escola inclusiva deve ser uma escola líder em relação às demais escolas, conforme relata Almeida (2005), adequando-se à padrões de desempenho por parte de todas as crianças envolvidas, na qual os professores estejam mais próximos dos alunos na captação das suas maiores dificuldades. Expões ainda que deva ser uma escola que proporcione mais apoio e continuidade no desenvolvimento profissional, uma rede de suporte para superação das suas maiores dificuldades, e que esteja integrada à sua comunidade, tendo os pais como parceiros. Os critérios de avaliação antigos deverão ser mudados para atender às necessidades dos alunos portadores de deficiência.

Em outra visão, como para Monteiro (2004), a educação inclusiva

deve assegurar um conjunto de recursos e serviços educacionais, organizados institucionalmente para apoiar, complementar, suplementar e até substituir os serviços educacionais comuns, garantindo o atendimento às diferenças dentro da diversidade humana. Diz ainda à autora que o compromisso dos educadores deve garantir a educação escolar e promover o desenvolvimento pleno do indivíduo, em todos os níveis, etapas e modalidades da educação. 
Para que haja educação inclusiva são necessárias várias ações na escola, na sociedade, na família, como: melhor investimento na formação do professor, proporcionando-Ihe meios criativos para que elabore planejamentos eficazes para as aulas e desenvolva a percepção das diferenças e das possibilidades das pessoas com deficiência, aprendendo a lidar com necessidades e alternativas; adaptações na escola, conforme estipulam as leis que amparam os deficientes, facilitando-lhes 0 acesso; assistência à saúde; qualificação profissional; estímulo e facilidade à prática de esporte; cultura e lazer; prática de ética, moral, religião, amor ao próximo.

Segundo Mantoan (2005),

para haver um projeto escolar inclusivo são necessárias mudanças nas propostas educacionais da maioria das escolas, uma nova organização curricular idealizada e executada pelos seus professores, diretor, pais, alunos e todos os que se interessam pela educação na comunidade onde está a escola. Para ela, a escola inclusiva caracteriza-se por ter a progressão no ensino de forma sincrônica e organizada em ciclos de formação e de desenvolvimento, e não serial e linear, como acontece nas escolas.

Cabe ressaltar que as concepções sobre os indivíduos portadores de qualquer tipo de deficiência devam ser traçadas a partir do levantamento sobre como essas pessoas se posicionam na sociedade, como elas vivem e lidam com a deficiência, "conhecendo suas expectativas, necessidades e alternativas, para que se possa realmente pensar nas dificuldades e conquistas desses excluídos e na possibilidade de concretização dos seus direitos." (GODOY, 2000).

\subsection{Quem são as pessoas excluídas?}

Segundo a revista Linhas Críticas da Universidade de Brasília (2011), no Brasil, alterações como a ampliação do ensino fundamental para nove anos e o piso salarial nacional para os professores do magistério público da educação básica, vem mudando o cenário escolar. Mas esses avanços ainda não são suficientes para alcançar objetivos de transformação na educação.

Segundo levantamento realizado pela UNESCO (2008)

é verdade que, quando se leva em consideração apenas o acesso, o Brasil está prestes a atingir o objetivo de universalização da educação obrigatória. Entretanto, sua pior situação está no indicador de qualidade, com uma desastrosa taxa de evasão na $5^{\text {a }}$ série: entre os 129 países avaliados, "o Brasil ocupa a 93a posição. Além disso, encontra-se em risco de não reduzir 
pela metade a taxa de analfabetismo e de não alcançar a paridade de gêneros nos ensinos fundamentais e médios" (UNESCO, 2008, p. 12).

É evidente que para assegurar o cumprimento desses compromissos, são necessários estudos e pesquisas que analisem e discutam a realidade do ensino brasileiro, visando superar os entraves e fortalecer as experiências de sucesso. Por que e como são excluídas as pessoas com NEE?

Ao buscar ilustração sobre para os questionamentos, é possível perceber a diversidade dos relatos.

Conforme matéria jornalística apresentada pela autora Botelho (2009) descrito no site da Folha de São Paulo on line, Doralice da Silva Nascimento, 45, mãe de Anderson, 25, Alexandre, 23, e André, 19, que nasceram cegos, passaram por essas duas situações: superprotegeu o primogênito por não aceitar o problema de início, mas mudou de atitude quando os outros filhos nasceram também sem enxergar. "Quando soube que o Alexandre era cego, procurei ajuda em uma escola especializada. Passei a aceitar a condição deles e a entender que precisavam aprender a se virar sozinhos, pois eu não poderia ajudá-los para sempre"

Segundo a psicóloga e psicanalista Ana Cristina Marzolla (2009), professora da PUC-SP, a maneira como os pais encaram a condição do filho depende de uma série de fatores, como o tipo e o grau de limitação da criança, a estrutura familiar, a relação do casal e a personalidade de cada um deles. "E esse comportamento não é estanque, ele muda com o tempo."

O psicólogo Roberto Benedito, do Departamento de Desenvolvimento Humano e Reabilitação da Unicamp, posiciona-se relatando que os pais precisam encarar a realidade dos filhos e trabalhar conforme as limitações que a deficiência impõe.

A criança precisa de estimulação e de recursos que facilitem sua vida, mas tem que aprender a conviver com o mundo com naturalidade. Na prática, isso nem sempre acontece. Não é difícil encontrar pais que protegem seus filhos com deficiência além do que seria recomendado. Em parte, segundo Marzolla, essa atitude se deve ao fato de eles projetarem no filho sua própria fragilidade diante da situação, à culpa que sentem por terem gerado um filho com deficiência ou por não terem conseguido evitá-la- e aos sentimentos ambivalentes, de amor e de rejeição, em relação à criança. Para Ana Cristina Marzolla, a super proteção faz com que a criança tenha uma auto imagem de fragilidade, impede-a de conhecer seus recursos e cria dificuldade para lidar com a frustração. "Isso ocorre também com filhos não deficientes, mas uma criança com deficiência física, dependendo do grau de super proteção, pode não desenvolver toda a sua capacidade cognitiva. 
O psiquiatra Geraldo Possendoro, professor do curso de atualização de Medicina Comportamental da Unifesp, relata que o equilíbrio é imprescindível especialistas podem auxiliar quanto aos procedimentos mais adequados. Para 0 psiquiatra, os responsáveis "devem procurar, o tempo todo, um balanceamento entre ajudar a criança em coisas que ela não consegue fazer sozinha e estimulá-la a resolver às outras. É preciso bom senso, o máximo de orientação técnica e flexibilidade."

\title{
1.5 Papel da escola inclusiva
}

É fundamental a reflexão nos meios políticos, educacionais e sociais sobre a educação inclusiva, a que ela pode levar, como e por quem pode ser construída.

Segundo Prieto (2000), a inclusão é uma possibilidade que se abre para o aperfeiçoamento da educação escolar e para o benefício de todos os alunos com e sem deficiência; ensinar é marcar um encontro com o outro, e a inclusão escolar provoca, basicamente, uma mudança de atitude diante do outro, esse que é alguém especial e que requer do educador ir além.

Nesse sentido, é o que afirma Soares (2009) apud Ferreira (2006, p. 231) quando relata que,

\begin{abstract}
a aula inclusiva visa responder à diversidade de estilos de aprendizagem na sala de aula; então, qualquer ação de desenvolvimento e aperfeiçoamento de práticas de ensino e aprendizagem de professores para a inclusão deve ajudá-los a refletir sobre formas de levantamento de informações sobre seu/sua/s aluno (a)s e planejamento de diversas atividades que abranjam os estilos de aprendizagem individual.
\end{abstract}

Seguindo as idéias de Monteiro (2004), a inclusão dessa clientela especial, que apresentam NEE, "na rede regular demanda não apenas a matrícula do aluno ou a permanência física junto com aqueles considerados normais, mas a oportunidade de serem revistas concepções e paradigmas." Cabe ressaltar a importância, acima de tudo, quanto ao respeito pelos limites desses indivíduos, para se aprender a conviver. Monteiro (2004) relata também que,

para atender às diferenças e às necessidades especiais, é preciso mudar o olhar da escola, pensando não a adaptação do aluno, mas a adaptação do contexto escolar aos alunos, romper barreiras humanas e arquitetônicas, criando novos conceitos, dando novos sentidos, dando no significado a aprendizagem e, consequentemente, o desenvolvimento humano. 
A situação quanto aos procedimentos no que diz respeito à educação, é completada com questões de infraestrutura e recursos aplicados nesse sentido. Conforme descrito na alínea II, do artigo 70 da LDB/96, os recursos públicos que são conferidos à educação deverão ser aplicados garantindo o desenvolvimento do ensino público, compreendendo a "aquisição, manutenção, construção e conservação de instalações e equipamentos necessários ao ensino” (LDB/96).

Várias concepções são apresentadas quanto ao processo ensino/aprendizagem. Conforme Bragança e Oliveira (2005), as opiniões dos pesquisadores divergem quando a questão é eficiência ou não dessas políticas. "Enquanto Sowell declara-se, veementemente, contra a adoção dessa política, que para ele só tem gerado mais discriminação nos países que a adotaram, outros vêem tal política como sendo positiva e necessária. (BRAGANÇA E OLIVEIRA, 2005. p. 226)

As proposições seguem que, "para vários pesquisadores brasileiros, as medidas são necessárias e benéficas, com função reparadora e inclusiva, pois funcionam como um instrumento de promoção de eqüidade para as minorias negras e indígenas." (BRAGANÇA E OLIVEIRA, 2005. p. 227)

É importante, segundo Bruno (2006, p. 16), que

\begin{abstract}
a implementação de um projeto para educação inclusiva seja proveniente de vontade política, planejamento e estratégias para capacitação continuada dos professores do ensino regular em parceria com professores especializados, dirigentes e equipe técnica dos centros de educação infantil, visando construir e efetivar uma prática pedagógica que lide com níveis de desenvolvimento e processos de aprendizagem diferenciados, buscando juntos a solução dos conflitos e problemas que surjam nesse processo.
\end{abstract}

Dessa forma, percebe-se a importância da inclusão abrangendo todo contexto no que se refere à qualidade de ensino. O quadro pedagógico, além das questões estruturais devem, portanto, estarem associadas para considerar a inclusão dos alunos com NEE no ensino regular, como uma proposta de reforma no sistema educacional e para alcançar novas perspectivas para a resolução dos problemas que norteiam a educação como direito de todos. 


\section{Deficiência Intelectual}

\subsection{Conceito}

Segundo conceito da Associação Americana de Deficiência mental, trata-se de um funcionamento intelectual inferior à média (QI), associado a limitações adaptativas em pelo menos duas áreas de habilidades (comunicação, auto cuidado, vida no lar, adaptação social, saúde e segurança, uso de recursos da comunidade, determinação, funções acadêmicas, lazer e trabalho), com início antes dos 18 anos.

Em 1995 o simpósio Intellectual Disability: programs, policies, and planning for the future da Organização das Nações Unidas - ONU, altera o termo deficiência mental por deficiência intelectual, no sentido de diferenciar mais claramente a deficiência mental da doença mental (quadros psiquiátricos não necessariamente associados a déficit intelectual). Em 2004, em evento realizado pela Organização Mundial de Saúde e Organização Pan-Americana da Saúde o termo deficiência é consagrado com o documento "Declaração de Montreal sobre Deficiência Intelectual".

\subsection{Causas}

As causas da deficiência intelectual são inúmeras e complexas, envolvendo fatores pré, peri e pós natais. O diagnóstico da causa é muito difícil, englobando fatores genéticos e ambientais, como quadros genéticos, infecções e drogas na gravidez, dificuldades no parto, prematuridade, meningites, traumas cranianos, etc. Em países desenvolvidos, em $42 \%$ dos casos não se encontram "pistas" da origem da deficiência; $29 \%$ é claramente genética, 19\% provavelmente genética e 10\% é ambiental. Existem medidas que podem ajudar a prevenir a deficiência, embora ela possa ocorrer em qualquer família, independente de idade, sexo, classe social, etc.

A deficiência intelectual pode ter várias causas, entre as principais estão os: fatores genéticos, perinatais (ocorridos durante a gestação e o parto) e pós-natais. 0 diagnóstico correto dos fatores causais no momento do nascimento pode não só amenizar os sintomas (prevenção secundária) mas até mesmo evitar o dano cerebral a exemplo da fenilcetonúria. 
Os fatores genéticos sejam cromossomos ou genes estão classificados em síndromes que muitas vezes recebem o nome de seus identificadores (Síndrome de Down, Síndrome de Rett, Doença de Tay-Sachs etc.) podem ser hereditários (recessivos ou dominantes) ou associados à gametogênese como no caso da Síndrome de Down.

Deficiência intelectual corresponde a expressões como insuficiência, falta, falha, carência, imperfeição associadas ao significado de deficiência (do latim deficientia) que por si só não definem nem caracterizam um conjunto de problemas que ocorrem no cérebro humano, e leva seus portadores a um baixo rendimento cognitivo, mas que não afeta outras regiões ou funções cerebrais.

A principal característica da deficiência intelectual é a redução da capacidade intelectual (QI), situadas abaixo dos padrões considerados normais para idade, se criança ou inferiores à média da população, quando adultas. A pessoa com deficiência na maioria das vezes apresenta dificuldades ou nítido atraso em seu desenvolvimento neuropsicomotor, aquisição da fala e outras habilidades (comportamento adaptativo conceptuais, sociais ou práticos). A definição da AAMR (2002) assinala ainda que tais incapacidades têm início antes dos 18 anos, obviamente distinguindo o retardo mental das demências.

\subsection{Prevenção}

Aconselhamento genético para famílias com casos de deficiência existentes, casamentos entre parentes, idade materna avançada (nestes casos temos uma maior chance de ocorrência ou recorrência de Síndrome de Down).

Acompanhamento pré-natal adequado diagnostica infecções ou problemas maternos que podem ser tratados antes que ocorram danos ao feto. Além disso, uma gestação com alimentação e práticas de vida saudáveis também favorecem o desenvolvimento adequado do feto. O Teste do Pezinho, obrigatório em território nacional, é a maneira mais efetiva de prevenção da deficiência intelectual em casos de fenilcetonúria e hipotireoidismo congênito. O Teste do Pezinho não faz diagnóstico de Síndrome de Down.

Do ponto de vista pós-natal, a aplicação de vacinas, alimentação adequada, ambiente familiar saudável e estimulador, cuidados relacionados aos acidentes na infância também são poderosos aliados. 
A pessoa com deficiência intelectual tem, como qualquer outra, dificuldades e potencialidades. Seu tratamento consiste em reforçar e favorecer o desenvolvimento destas potencialidades e proporcionar o apoio necessário às suas dificuldades.

A inclusão social é um instrumento extremamente importante na determinação da qualidade de vida desta pessoa, pois the permite o acesso a todos os recursos da comunidade, que favorecerão o seu desenvolvimento global.

\subsection{Diagnóstico}

Ao longo da história já foram utilizadas expressões como idiotia, cretinismo, debilidade, imbecilidade. A Classificação internacional de doenças (CID), em função do típico atraso de desenvolvimento que os portadores de tais síndromes apresentam, utiliza a expressão Retardo Mental, subdividindo este grupo em quatro categorias de gravidade (leve, moderada, grave e profundo) em função da sua capacidade intelectual com ou sem outros comprometimentos do comportamento.

As pessoas com esse transtorno, são dependentes de cuidadores e necessitam de atendimento multiprofissional (incluindo: médico, fisioterapeuta/ terapeuta ocupacional, fonoaudiólogo, psicólogo, pedagogo (psicopedagogia) entre outros) a fim de minimizar os problemas decorrentes da deficiência. Quanto mais cedo houver um diagnóstico e mais precoce for a intervenção melhores serão os resultados. As técnicas exercidas por diversos profissionais de reabilitação e puericultura para identificar precocemente lesões e intervir são denominadas: Avaliação do Desenvolvimento e Exame Neuropsicomotor Evolutivo ou psicomotor e Teste de Inteligência ou Quociente de inteligência, além do diagnóstico das informações provenientes da clínica médica para identificar a síndrome genética ou natureza da lesão que possívelmente causou o dano cerebral e/ou seus sinais e sintomas.

As clássicas definições da deficiência mental, a exemplo da Associação Americana Deficiência Mental têm como referência a limitação da atividade intelectual (leia-se praticamente habilidades lógico matemáticas) e a capacidade de adaptação (leia-se socialização) contudo ambos conceitos, aqui referidos, podem ser ampliados em função das suas distintas aplicações.

Para Piaget a inteligência é um prolongamento da adaptação orgânica, o progresso da razão consiste numa conscientização da atividade organizadora da 
própria vida. Essa definição, uma das muitas possibilidades de definir lógica e inteligência em seus estudos, revelam sua opção de pesquisa a partir de um conceito básico da biologia moderna, a adaptação, sem o qual não poderíamos compreender as relações entre forma e função e/ou a teoria da evolução.

A deficiência intelectual é resultado, quase sempre, de uma alteração na estrutura cerebral, provocada por fatores genéticos, na vida intra-uterina, ao nascimento ou na vida pós-natal. O grande desafio para os estudiosos dessa característica humana, é que, em quase metade dos casos estudos essa alteração não é conhecida ou identificada e quando analisamos o espectro de patologias que tem a deficiência mental como expressão de seu dano nos deparamos com um conjunto de mais de 200 doenças entre as mais comuns estão a Síndrome de Down e Paralisia cerebral.

Síndrome de Down é um conjunto de características específicas (hipotonia, face com perfil achatado, crânio braquicéfalo, olhos amendoados ou fissuras palpebrais oblíquas, língua protrusa, pescoço curto, prega palmar transversal única, entre outros) e não uma doença. Complementando Síndrome de Down é uma anomalia causada durante a formação do feto que pode ocorrer com qualquer pessoa, chamada de Trissomia do Cromossomo 21. Para se confirmar essa trissomia é preciso se fazer um exame genético (a partir de linfócitos ou outra célula coletada no sangue) chamado Cariótipo.

Esse exame feito após nascimento poderá identificar três tipos de trissonomia. O cromossomo sempre é duplo, apresentando portando duas pernas e no caso da trissomia do 21, ele apresenta três pernas : 1ำ Trissonomia(21) - Todas as células apresentam alterações, cerca de $95 \%$ das pessoas ; $2^{\circ}$ trissomomia da translocação cerca de $4 \%$ das pessoas apresentam essa modificação ou seja uma das pernas superior ou inferior muda de posição. $3^{\circ}$ caso a trissonomia moisaicismo,algumas células apresentammtais modificações e ooutras são normais. 


\section{Educação Especial no Município de Ipatinga}

\subsection{Atendimento da Educação Especial em Ipatinga}

A Educação Especial em Ipatinga, data da década de 90, quando teve início o atendimento aos deficientes auditivos na Escola Municipal Barnabé. Em 1998 foi criado o Centro de Atendimento à criança com NEE. Para atender alunos com desvio no desenvolvimento global. Já em 2001 cria-se o COM TATO para atender deficientes visuais de Ipatinga e região.

Criado em 2004, o município de Ipatinga-MG conta com o CENAM - Centro de Atendimento Especializado Hebert de Souza, , uma vez que não possuem salas de recursos multifuncionais nas escolas municipais de ensino regular. Nessas instituições o professor regente é quem faz o atendimento ao aluno com NEE. $O$ Centro funciona como local de atendimento educacional complementar com sede específica, servindo, quando há vagas, as 48 escolas municipais e prioriza o atendimento aos alunos não alfabetizados. Esse atendimento ocorre no contra turno (um horário é na escola regular e o outro no Centro). Quando o aluno apresenta patologia que requer assistência (dependências), ainda se encaminha a Escola Especial - Associação de Pais e Amigos dos Excepcionais (APAE).

Em 2006 Cria-se o Programa de Atendimento Especializado para Jovens e Adultos (PRAEJA), nas escolas municipais de EJA (Ensino de Jovens e Adultos).

\subsection{Objetivos do atendimento da Educação Especial em Ipatinga}

Melhorar a qualidade do ensino para educandos com NEE. Reduzir as desigualdades sociais escolares, no tocante ao acesso e a permanência com sucesso na escola. Redimensionar práticas pedagógicas de forma a favorecer e apoiar a inclusão de educando com NEE. Definir condições para a terminalidade dos educando que não puderem atingir o nível exigido para a conclusão do Ensino Fundamental. Incentivar a realização de estudos e pesquisas, especialmente através de parcerias com instituições de ensino superior, sobre as diversas áreas de conhecimento relacionados aos educandos que apresentam NEE. Estabelecer critérios adequados para avaliar educandos com NEE. 


\subsection{Formação continuada e avaliação}

A educação inclusiva pressupõe a formação continuada dos educadores que necessitam conhecer melhor acerca das necessidades educacionais especiais dos educandos, para contemplar a diversidade presente nos núcleos do centro de atendimento Hebert de Souza.

Considerando a abrangência e a relevância da atuação dos educadores como mediadores no processo de desenvolvimento a aprendizagem dos educandos, será assegurada formação permanente específica para os mesmos, visando um atendimento pautado em sólidos referenciais teóricos e práticos.Além de participação em congressos palestras.

Serão realizadas avaliações semestrais tendo como registro o relatório descritivo, identificando potencialidade, necessidades educativas e 0 desenvolvimento do educando.

\subsection{Terminalidade Específica}

No atendimento a alunos cujas as necessidades educacionais especiais estão associadas a grave deficiência mental ou multipla,há necessidades de apoi e ajuda intensos e continuos,bem como adaptações curriculares significativas. Isso não deve estabelecer uma escolarização sem horizonte definido, seja em termos de tempo ou em termos de competências e habilidades a serem desenvolvidas. As escolas portando devem adotar sistemas de avaliação pedagógica,certificação e encaminhamento para alternativas educacionais que concorram para ampliar as possibilidades de inclusão social e produtiva dessa pessoa.

Sendo esgotadas todas as possibilidades pedagógicas estabelecida no Artigo 32, 1 da LDBEN: - as escolas devem lhe fornecer-Ihes certidão de conclusão de escolaridade, denominada de terminalidade Específica, após cumprida a garantia de $50 \%$ de tempo a mais para a conclusãodo Ensino Fundamental.

\subsection{Transporte}

Os educandos diagnosticados para atendimento nos núcleos de Centrode Atndimento Especializado, terão direito ao transporte. 


\section{OBJETIVOS}

\subsection{Objetivo Geral}

Diagnosticar os aspectos históricos da socialização presentes na escola e família que atrapalham a inclusão dos alunos com NEE.

\subsection{Objetivos específicos}

$\checkmark$ Descrever o contexto da inclusão escolar;

$\checkmark$ Analisar os seguimentos escolares no que tange à inclusão escolar;

$\checkmark$ Propor junto aos segmentos envolvidos no processo educacional uma reflexão sobre a necessidade de uma educação inclusiva. 


\section{METODOLOGIA}

\subsection{Fundamentação Teórica}

Nos estudos aqui realizados sobre a natureza do desenvolvimento humano há concepções naturalistas e ambientalistas. As naturalistas valorizam o desenvolvimento biológico, que só vêem o sucesso do indivíduo a partir da transmissão cultural, por outro lado a ambientalista defende que através da interação permanente do sujeito com o contexto sociocultural, faz com que o mesmo possa transformá-lo. São quatro as teorias que procuram compreender e explicar o desenvolvimento: A da maturação biológica, (que acredita que as mudanças vêem com o tempo em conseqüência dos genes que herdamos do nosso genitores), a abordagem ambientalistas ou comportamentalista (que defende que todo desenvolvimento vem da experiência vivenciada no seu ambiente), a do construtivismo piagetiano (que diz que o conhecimento humano acontece pela interação entre organismo humano e ambiente), e por último a teoria histórico cultural de Vigotski( que preconiza que a herança biológica e o ambiente interage indiretamente, intermediados pela cultura,que é fator preponderante para o desenvolvimento humano), em seu trabalho diz existir no ser humano uma continuidade e uma ruptura entre o que biológico e o que é cultural: o cultural supõe o biológico, ao mesmo tempo que o transforma.

Vigotsky (1994) estabeleceu a Lei Genética Geral do Desenvolvimento Cultural,que afirma que toda função do desenvolvimento cultural da criança aparece em cena duas vezes, em dois planos; primeiro no plano social e depois no psicológico, a princípio entre os homens como categoria interpsíquica e logo no interior da criança como categoria intrapsíquica(p.64).

Essa teoria é composta de quatro conceitos fundamentais: internalização, a mediação, a zona de desenvolvimento proximal, relação entre aprendizagem e desenvolvimento. A internalização transforma as experiências intersubjetivas em intrasubjetivas, ou seja, do externo, social, para o interno, mental. A mediação que se trata na utilização dos sistemas de signos, como linguagem, a leitura, a escrita e o cálculo. A zona de desenvolvimento proximal, que trata do conhecimento que estão ainda a caminho, que ainda não consegue ser realizados com autonomia 


\subsection{Contexto da Pesquisa}

A pesquisa foi realizado numa escola com 30 anos de atuação na comunidade escolar, que atende em torno de mil e cem alunos, nos turnos matutino e vespertino, com alunos que variam a idade entre 07 e 14 anos, aproximadamente.

O prédio é antigo, mas bem conservado. Possuem 20 salas de aula, uma biblioteca com grande acervo literário, duas salas de inclusão digital - sendo uma sala com 06 mesas pedagógicas do projeto positivo que atende crianças até o $5^{\circ}$ ano; a outra sala com 10 computadores para atendimento do $6^{\circ}$ ao $9^{\circ}$ ano, ambas com acesso à internet. Conta também com uma sala de Recursos para atendimento especializado aos alunos com necessidades educacionais especiais no contra turno. Além desta sala para atendimento especial, possui parceria com o CENAM (centro de Atendimento multidisciplinar) que atende no contra turno alunos com grande dificuldade de aprendizagem (São considerados alunos com dificuldades de aprendizagem, alunos que não demonstram avanços, após diversas tentativas na sala regular e não conseguem alfabetizar, além da aula regular são atendidos por um grupo de professores que oferece um atendimento mais individualizado). $\mathrm{Na}$ área externa, a escola conta ainda com quadra coberta, 02 salas para atendimento de projetos que auxiliam os professores do $3^{\circ}$ ano e $5^{\circ}$ ano (finais de ciclos), jardins, cantina, sala de funcionários, sala de coordenação pedagógica equipadas com computadores acesso a internet, secretaria também informatizada com sistema integrado de informações, entre secretarias das escolas municipais e a Secretarias municipal de Educação.

Apresenta uma composição diretiva composta por uma diretora, uma vicediretora e três coordenadores pedagógicos. Conta com um quadro efetivo de 85 funcionários, sendo 56 professores todos com nível superior e mais de $85 \%$ com pós - graduação em suas respectivas áreas de atuação. O quadro de funcionários da escola se completa com vigilantes, cantineiros e auxiliares de limpeza a carga horária deste variam de 06 a 08 horas diárias. A carga horária dos professores é distribuída em 16 horas de regência e 4 horas destinadas à coordenação pedagógica (planejamento), podendo ser estendida sua carga horária por mais 90 horas, caso queira e quase $100 \%$ destes estendem sua carga horária.

Apresenta-se como uma escola de referência e atende uma grande demanda. Grande parte de seus alunos residem próximo, tanto que seu deslocamento é feito a 
pé, outros utilizam o transporte coletivo (ônibus) custeado pela prefeitura ou ainda, peruas particulares, bicicletas ou carro da família. Localizada na periferia, o bairro possui saneamento básico, ruas asfaltadas e bem sinalizadas. O portão de entrada da escola está situado numa rua com pouco movimento, mas o entorno da escola possui um grande fluxo de carros,

Requerendo, portando, dos pais, certo cuidado para garantir a segurança de seus filhos.

O processo de enturmação é heterogêneo, a escola trabalha em forma de ciclo embora a idéia que mais prevalece é a da seriação. Os alunos, público alvo desta pesquisa, estão distribuídos em várias turmas e ciclo diferentes que vai do fundamental I até o fundamental II e estão na escola há mais de cinco anos.

\subsection{Participantes}

Os participantes são compostos de educadores: professores, pais e da observadora. Considero que todos não se identificam como participantes da história destes educando. Sempre que relatam falam como se observassem de fora, não se incluem. Os professores têm em torno de 20 anos ou mais que trabalham na rede, são dedicados e se interessam pela causa dos mesmos, mesmo não sabendo o que fazer para melhorar o desempenho dos mesmos.

O estudo foi composto por uma entrevista semi estruturada com os educadores tratando do tema: Se sente preparado para trabalhar com alunos com NEE (relacionado ao objetivo). A fim de se iniciar o estudo, foram feitas várias sessões de observação em sala de aula com duração aproximada de 60 (minutos) cada. Foram feitas observações também durante o recreio, entrada e saída dos turnos, participação em atividades de abertura de turno, auditório e festas.

\section{$5.4 \quad$ Materiais}

Foram utilizados materiais como internet, instrumentos de suporte para apresentação e objetivos da pesquisa aos professores voluntários (netbook, tela de projeção e data show), folhas $\mathrm{A} 4$, impressora e tinta para impressão do questionário e caneta. Quanto aos recursos humanos, foi necessário o contato 
inicial com a Secretaria de Educação do Município de Timóteo, para esclarecimentos sobre a pesquisa.

Posteriormente, a coordenação e demais corpo pedagógico da instituição de ensino pesquisada, foi informada sobre a pesquisa que seria realizada com os educadores que preenchessem os quesitos, conforme descrito abaixo no Procedimento de Construção de Dados, necessários para o referido estudo.

\subsection{Instrumento de Construção de Dados}

Com o intuito de conhecer o perfil do professor que atua em sala de aula do ensino regular e ao mesmo tempo lida com a realidade da inclusão de alunos com NEE e suas concepções, utilizou-se três questionários, destinados aos seguintes seguimentos: questionário dirigido aos pais, questionário destinado aos alunos (as), questionário destinado aos professores da instituição escolar.

\subsection{Procedimento de Construção de Dados}

A instituição escolhida teve como objetivo possuir alunos com NEE, possuir profissionais que tenha vontade de fazer a inclusão dos mesmos. Ser uma escola de periferia, atender alunos de diferentes níveis sociais e econômico, e ter alunos do1ํㅜ ciclo até o $4^{\circ}$ ciclo, ou seja, do $2^{\circ}$ ano ao 9ํano do Ensino Fundamental, e também possuir sala de Recursos para atendimento.

Os alunos eu já os acompanho desde a entrada na escola, portanto há anos. Conheço os profissionais que trabalham nesta instituição e sei de seus anseios e suas necessidades como também seu compromisso sério com esta causa.

Para obtenção das informações nesse âmbito, foram distribuídos questionários (APÊNDICE $A, B$ e $C$ ) direcionados respectivamente aos profissionais da escola, aos membros da família e aos alunos.

Os voluntários da pesquisa receberam informações gerais, inclusive o objetivo sobre a pesquisa conforme o Termo de Consentimento Livre e Esclarecido (ANEXO D). Foi disponibilizado à eles contatos (e-mail e número do celular) para quaisquer possíveis dúvidas posteriores. Quanto à abordagem se deu de forma natural, quando coloquei a necessidade de fazer uma entrevista,nenhum se opôs, pelo contrario estão curiosos para ver o resultado do trabalho. 
Em comum acordo, foi estipulado um prazo de duas semanas para respostas e devolução dos impressos. Nesse encontro, a pesquisadora colheu depoimentos de relatos relacionados ao tema, onde os professores puderam dissertar sobre seus medos e expectativas de maneira livre. Esses depoimentos foram sendo redigidos pela pesquisadora, quando no final, o voluntário tomava conhecimento do que foi relatado, assinando como forma de acordo, através do Termo de Consentimento Livre e Esclarecido.

\subsection{Procedimentos de Análise de Dados}

Os dados da presente pesquisa foram examinados com base nas fundamentações teóricas do estudo, opinando conforme o conhecimento adquirido, os quais serão relatados no tópico seguinte.

Caracteriza os professores abordados neste trabalho o tempo de experiência de 10 anos ou mais na profissão, da incerteza do trabalho estar sendo eficaz, com tais educando e da falta de formação para ajudar a clarear, embora não deixe de trabalhar dentro do que acham necessário para seus alunos com NEE. Os pais são agradecidos a escola por terem recebidos, tinham medos e receios de seus filhos não serem aceitos. Acham que os filhos são o são por vontade de Deus. Os alunos são tímidos, quando interpelados sozinhos, mas possuem expectativas de melhoras no futuro outros se apresentam conformados com a situação e se sentem incapazes mesmos 


\section{RESULTADOS E DISCUSSÃO}

A seguir, relacionam-se as tabelas que traduzem as características dos participantes e os procedimentos de coleta de dados de cada seguimento, bem como seus relatos.

TABELA 1- Características dos professores

\begin{tabular}{ccccccc}
\hline Professor & Sexo & $\begin{array}{c}\text { Tempo de } \\
\text { Magistério }\end{array}$ & Formação & Cursos & Outros cursos & $\begin{array}{c}\text { Número de } \\
\text { alunos em } \\
\text { processo de } \\
\text { inclusão e } \\
\text { seus }\end{array}$ \\
\hline P1 & F & 20 anos & Superior & Pedagogia & $\begin{array}{c}\text { Pós graduação } \\
\text { em } \\
\text { diagnos }\end{array}$ & $\begin{array}{c}1 \text { deficiência } \\
\text { mental leve }\end{array}$ \\
\hline P2 & F & 21 anos & Superior & Pedagogia & Alfabetização & $\begin{array}{c}\text { 1 deficiência } \\
\text { mental leve }\end{array}$ \\
\hline P3 & F & 10 anos & Superior & Pedagogia & Alfabetização & $\begin{array}{c}\text { 1 deficiência } \\
\text { mental leve }\end{array}$ \\
\hline P4 & F & 18 anos & Superior & Pedagogia & Alfabetização & $\begin{array}{c}\text { 1 deficiência } \\
\text { mental leve }\end{array}$ \\
\hline
\end{tabular}

Fonte: Dados do autor (2011)

Os professores aqui observados possuem de 10 a 20 anos de experiências (TABELA 1) na área educacional. Todos possuem graduação, mesmo assim sentem-se inseguros quando indagados sobre 0 atendimento de crianças com alguma deficiência. Os educadores se mostraram com boa vontade em recebê-los, porém falta informação sobre o que se pode realmente fazer diante de cada deficiência, se o caminho adotado é o melhor para criança, desde o tratamento pessoal até sobre o que se refere ao processo ensino/aprendizagem.

Ao se tratar do assunto, é unânime ao se sentirem desamparados com relações as informações sobre a deficiência. Dentre os depoimentos, destacou-se o seguinte: "Não fui preparado para trabalhar com esses tipos de crianças, não sei o que fazer" (P3). De alguma forma, é importante ressaltar que mesmo diante suas limitações se prontificam em ajudar a criança portadora de necessidade educacional especial.

Ao se defrontarem com esses alunos, buscam respaldo à coordenação pedagógica, mas nem sempre são atendidos devido a falta de formação específica. 
Relataram ainda que há solicitações dos encaminhamentos médicos e psicológicos para auxiliar como proceder com tal criança.

Embora o foco da pesquisa ter sido em deficiência intelectual, vale lembrar que as salas têm em média 30 alunos cada uma e tem outros tipos de deficiências, no mesmo espaço em média no mínimo 03 crianças por sala, alguns com alguma suspeitas de diagnóstico sendo trabalhado em parceria com outra escola e outros, apesar da dificuldade estampada ainda sem um diagnóstico prévio. A maioria dessas crianças que apresentam determinadas deficiências, não possui laudo médico, mesmo aquelas que conseguem ser atendidas regularmente pelos profissionais da saúde.

Os dados a seguir são provenientes do estudo realizado com mulheres que experimentaram a situação de ser mãe de uma criança deficiente e que concordaram em participar da pesquisa. Tem filhos atendidos pelo CENAM (Centro de Atendimento Multidisciplinar), que realiza um trabalho no contra-turno da escola regular.

TABELA 2 - Características dos pais

\begin{tabular}{ccccc}
\hline Mães & Sexo & Idade & Formação & Número de filhos \\
\hline M1 & F & 29 & $\begin{array}{c}4^{\circ} \text { ano do Ensino } \\
\text { Fundamental } \\
\text { 60 ano do Ensino } \\
\text { Fundamental }\end{array}$ & 04 \\
\hline
\end{tabular}

Fonte: Dados do autor (2011)

Os encontros com os responsáveis, conforme Tabela 2, aconteceram em várias sessões, com duração de 20 a 30 minutos cada uma. Aproveitou-se as convocações desses responsáveis por parte da instituição ou pelos professores, com intuito de constatar qual a melhor forma de lidar com esses educando e identificar a necessidade de cada um.

A família geralmente é representada, no contexto educacional, pela figura da mãe, $100 \%$ conforme Tabela 2 . Em reuniões, elas informam sobre seus filhos aos poucos quando indagados pelos professores, mas omitem ou não admitem, muitas vezes que os filhos têm algum tipo de problema. Essa situação propõe mais um 
desafio aos educadores e corpo pedagógico das instituições, uma vez que deveria ser a base mais sólida para resolução desses problemas.

Foi possível constatar que aos poucos, quando sentem confiança, a troca de informações responsáveis/educador se torna mais completa. Isso justifica o fato das várias convocações por parte da escola, para ir "desvendando" aos poucos as informações sobre estes educando.

Os respectivos dados foram coletados em novembro e dezembro de 2010 através de entrevistas, quando de sua convocação pela instituição para apresentarem resultados bimestrais de seus filhos (as).

Com o objetivo de compreender o que significa para a mãe ter um filho deficiente, foi necessário fazer o levantamento e buscar a compreensão da essência dos sentimentos que envolvem esta questão. As emoções e sentimento vivenciados com o nascimento do filho com deficiência são descritos pelas mães com grande sofrimento e pesar. A partir do momento da percepção que algo de errado está acontecendo com seu filho, fugindo da normalidade, uma perturbação assola seu equilíbrio emocional. Vivem elas uma experiência única e intransferível, permeada muitas vezes, por choro, solidão, sentimento de desamparo e uma grande ânsia por fugir da situação vivida.

Muitas das vezes que a mãe é chamada, ela demonstra viver grande conflito emocional e existencial, sentindo-se abandonada e sem forças para continuar lutando, se sentem enfraquecidas, injustiçada, luta com seus próprios sentimentos, opostos e contraditórios. O sentimento de rejeição manifestado pela mãe se concretiza em posturas de abandono, de superproteção e de negação da deficiência, configurando um estado de medo e ansiedade. A atitude de abandono caracteriza-se por não-investimento, seja de amor, de dedicação ou de cuidado ao filho e a mãe reage à situação vivenciada manifestando o direito de não desejar e não querer um filho deficiente, muitas vezes negando reconhecer a dificuldade do filho colocando a culpa hora no professor, ora na falta de amparo do companheiro.

Embora a mãe busque acessar fontes de apoio representadas pelos profissionais de saúde, apoio esse para o momento vivido e para o desenvolvimento do cuidado ao filho com maior segurança, não encontra o suporte necessário, pois a demora para um atendimento é longo até mesmo para um fonoaudiólogo costuma se esperar anos. Para demais dependem de encaminhamentos que também perdura por anos. Não receber as informações necessárias acerca da deficiência do filho 
significa, para a mãe, não estar sendo vista e respeitada como pessoa e, como ser humano, não ser respeitada em seus sentimentos, o que a leva a vivenciar sentimentos de descrença e desesperança. A mãe busca algum tipo de explicação quanto ao motivo pelo qual isso lhe aconteceu, preocupando-se quanto à causa exata da deficiência. Esse fato é frustrante, pois nem sempre é possível determinar o motivo da deficiência do filho.

À medida que a mãe transpõe os obstáculos emergidos com a deficiência do filho, a tristeza e o luto vão sendo substituídos pelo sentimento de alegria e felicidade. Vivencia intensamente os sucessos pelas conquistas e crescimentos pessoais e familiares, pois vibra com os pequenos avanços, faz questão de falar do que a criança já dá conta. Porém isso não ocorre com todas as mães observadas permanece muitas vezes na defensiva colocando a culpa na própria criança alegando falta de interesse dela, deixando-a sem a necessária atenção e apenas por conta da escola

TABELA 3 - Características dos alunos

\begin{tabular}{|c|c|c|c|c|c|}
\hline Alunos & Sexo & Idade & $\begin{array}{c}\text { Ano/ ciclo em que } \\
\text { está }\end{array}$ & $\begin{array}{c}\text { Data de } \\
\text { admissão na } \\
\text { escola }\end{array}$ & Alfabetizado \\
\hline A1 & $M$ & 13 & $\begin{array}{l}7^{\circ} \text { ano do Ensino } \\
\text { Fundamental }\end{array}$ & 02/2004 & sim \\
\hline A2 & M & 13 & $\begin{array}{l}6^{\circ} \text { ano do Ensino } \\
\text { Fundamental }\end{array}$ & $02 / 2004$ & $\operatorname{sim}$ \\
\hline A3 & $F$ & 11 & $\begin{array}{l}3^{\circ} \text { ano do Ensino } \\
\text { Fundamental }\end{array}$ & 02/2005 & Não \\
\hline A4 & M & 11 & $\begin{array}{l}\text { 50 ano do Ensino } \\
\text { Fundamental }\end{array}$ & 02/ 2006 & Não \\
\hline
\end{tabular}

Fonte: Dados do autor (2011)

Os alunos A1, A2, A3, A4 são unânimes em relatar que gostam da escola, principalmente dos colegas, sendo poucos aqueles que se referem aos demais 
colegas como sendo "chatos", ou seja, que praticam o bulling. Foi percebido também a timidez, na sua maioria, ao serem interpelados pelas perguntas.

Relatam que esperam aprender, mas ao mesmo tempo tem vergonha de expor suas dificuldades, por medo de serem repreendidos. Na comunidade onde residem, saem pouco, brincam quase sempre dentro de casa ou passam o dia inteiro sozinhos na companhia de irmão enquanto seus pais trabalham.

Com relação aos seus sonhos não diferem dos demais alunos, querem crescer, trabalhar, adquirir bens materiais (carros, motos, comprar casas grandes com piscina), enfim serem felizes, conforme os depoimentos dos alunos pesquisados.

Alguns expõem ainda que os colegas que mais gostam estão em outras salas e preferem brincar com eles durante o recreio, pois os de suas salas "são muito pequenos e as brincadeiras deles são sem graça ou quando vão brincar, como são bem maiores com relação aos colegas de classes, acabam machucando-os ou viceversa. O colega quando reclama de alguma coisa sobre eles sempre refere com as seguintes falas: "Aquele menino grandão da minha sala ou aquele que não sabe nada" (A3). Quando irão se referir aos colegas, não usam falar o nome do mesmo, referindo de forma pejorativa, sem identificá-lo pelo nome.

Através da proposta do trabalho de identificar situações capazes de descrever sobre a socialização, no que se refere à inclusão dos alunos com necessidade de educação especial e relacionando à realidade do município de Ipatinga, foi possível perceber que a dificuldade enfrentada há alguns anos, apresenta resquícios de todas as maneiras, ou seja, o preconceito e as dificuldades de se trabalhar com essas pessoas em prol de seu desenvolvimento ainda é um desafio para todas as esferas. Essa situação apresenta um agravante a partir do momento em que os educadores se vêem "perdidos" e não respaldados por informações suficientes para lidarem com a inclusão ou não exclusão. 


\section{CONSIDERAÇÕES FINAIS}

A inclusão não é um processo já pronto e acabado nas sociedades, e, sim, uma proposta que tem permeado a subjetividade social, se desenvolvendo e também encontrando resistências de diversas formas e por vários setores da sociedade e pessoas. Essa questão é um processo complexo e multifacetado, gerando a mobilização e provocando interesse e resistência de todas as esferas, uma vez que educação é direto de todos.

A pesquisa proporcionou a conclusão no sentido que a formação continuada, o sistema de constantes informações e atualização dos educadores é a melhor maneira de iniciar a implantação da inclusão educacional, não com o significado apenas de matricular os alunos, mas no sentido literal do ensino/aprendizagem. $O$ professor precisa ser capaz de realizar planejamentos eficazes, desenvolvendo a assimilação das diferenças e das competências das pessoas com deficiência, aprendendo a lidar com as particularidades.

Cabe ressaltar ainda que a socialização depende da teoria e da práticas desses profissionais diante as diversas situações surgidas em sala de aula de forma que a interação e integração dos alunos com NEE ocorra de maneira natural, sem pressão com resultados positivos para essa clientela e demais participantes do contexto.

No que tange sobre o percurso da criança no contexto da sociedade e considerando a abrangência da Paidéia, esta por sua vez não designa unicamente a técnica própria de preparar a criança para a vida adulta, mas o resultado do processo educativo que se prolonga por toda a vida, muito além dos anos escolares, um desenvolvimento pleno do homem. Dessa forma, esse desenvolvimento pleno tem o sentido da educação e cultura, sem perder a proposta da "[...] responsabilidade social, de uma reflexão sobre a sociedade [...] e a busca de caminhos e soluções para se constituir um mundo novo onde não só prevaleça a razão, mas o amor, a solidariedade; uma nova educação que deixe de ser produto para se tornar serviço" (CARNEIRO, 2004).

Segundo Mantoan (2005), a escola inclusiva, com intuito ainda de socialização dos alunos "[...] caracteriza-se por ter a progressão no ensino de forma 
sincrônica e organizada em ciclos de formação e de desenvolvimento, e não serial e linear, como acontece nas escolas."

Portanto, a educação inclusiva e a proposta de socialização proveniente da inclusão "deve assegurar um conjunto de recursos e serviços educacionais, organizados institucionalmente para apoiar, complementar, suplementar e até substituir os serviços educacionais comuns, garantindo 0 atendimento às diferenças." (MONTEIRO, 2004) Há ainda a necessidade de várias ações nas instituições de ensino, nas comunidades, na família. 


\section{REFERÊNCIAS BIBLIOGRÁFICAS}

\section{ALMEIDA, M. da S. R. Manual informativo sobre inclusão informativo} para educadores. Disponível em

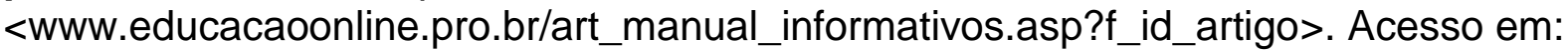
15 mar 2011.

ASSEMBLÉIA GERAL DA ONU. Resolução no 217, de 10 de dezembro de 1948. Declaração Universal do Direitos Humanos. Disponível em $<$ http://portal.mj.gov.br/sedh/ct/legis_intern/ddh_bib_inter_universal.htm>. Acesso em 30 jan 2011.

BATTAGLIA, L. Inclusão escolar: Práticas e compromissos. São Paulo, Ed. Globo, 2009.

BRAGANÇA, M. das G. V.; OLIVEIRA, Z. M. F. de. Educação Inclusiva: significado e realidade. V.11. N. 21. P. 217-228, jul/dez. 2005. Disponível em <http://www.fe.unb.br/linhascriticas/linhascriticas/artigos/geral.htm>. Acesso em 11 mar 2011

BRASIL. Lei no 8969 de 13 de julho de 1990. Dispõe sobre o Estatuto da Criança e do Adolescente. In: Coletânea de Leis. $3^{a}$ ed. Belo Horizonte: Conselho Regional de Serviço Social 6" Região. ma/2004. p. 227-291.

BRASIL. Ministério da Educação. Diretrizes nacionais para a educação especial na educação básica. Secretaria de educação Especial. MEC/SEESP, 20011. 79p. COELHO, C.M. M. Inclusão Escolar. In: Desenvolvimento humano, educação e inclusão escolar. Brasília: UNB, 2010. p. 55-72.

BRASIL. Lei $\mathrm{n} . \mathbf{0}$ 7.853, de 24 de outubro de 1989. Dispõe sobre o apoio às pessoas portadoras de deficiência, sua integração social, sobre a Coordenadoria para a Integração da Pessoa Portadora de Deficiência - CORDE. Disponível em <http://portal.mec.gov.br/seesp/arquivos/pdf/lei7853.pdf>. Acesso em 15 out 2010

BRUNO, M. M. G. Educação infantil: saberes e práticas da inclusão. 4. ed. Brasília: MEC/SEESP, 2006. 45 p. Disponível em $<$ http://portal.mec.gov.br/seesp/arquivos/pdf/introducao.pdf>. Acesso em $10 \mathrm{dez}$ 2011 
CARNEIRO, Roberto. Aprender a educar no século XXI. 2004. Palestra - Mestrado em Educação da UCB, Brasília, 2004. Não publicado.

CASTRO, M. H. G. de. A educação para o século XXI: o desafio da qualidade e da eqüidade. Brasília: Inep, 1999. Disponível em <www.inep.gov.br>. Acesso em 17 jan 2011.

ESPANHA. Declaração de Salamanca: Conferência Mundial sobre Necessidades Educativas Especiais; define princípios básicos da inclusão nos sistemas educativos regular. Espanha, 1994. Disponível em

<http://portal.mec.gov.br/seesp/arquivos/pdf/salamanca.pdf>. Acesso em 3 out 2010.

IPATINGA. Secretaria Municipal de Educação. Diretrizes Curriculares Municipais da Educação Especial de 15 de maio de 2008.

IPATINGA. Lei no 2100, de 04 de novembro de 2004. Instituiu o Centro Especializado Herbert de Souza. Secretaria Municipal de Educação.

KELMAN, C. A. Sociedade, educação e cultura. In: Desenvolvimento humano, educação e inclusão escolar. Brasília: UNB, 2010. p. 11-54.

MONTEIRO, M. da S. Ressignificado a educação: a educação inclusiva para seres humanos especiais. 2004. Disponível em <www.educacaoonline.pro.br>. Acesso em 20 fev 2011

MONTOAN, M. T. E. Uma escola de todos, para todos e com todos: o mote da inclusão. 2005. Disponível em <www.lite.fae.unicamp.br/papet/2002/nt/ta1.5.htm>. Acesso em 20 fev 2011.

MRECH, L. M. O que é educação inclusiva? 2005. Disponível em

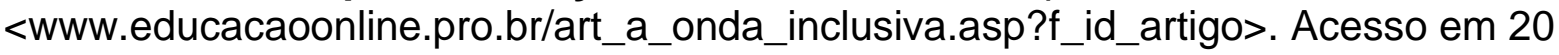
fev 2011

SASSAKI,R.K. Inclusão: Construindo uma sociedade para todos. Rio de Janeiro: WVA, 1997.

SOWELL, Thomas. Affirmative action around the world: an empirical study. New Haven: Yale University Press, 2004. 
TUNES, E; et. al. O Professor e o Ato de Ensinar. São Paulo: Scielo, Caderno de pesquisa. Vol. 35, no 126, set/dez 2005. p. 689-698. Disponível em <http://www.scielo.br/pdf/cp/v35n126/a08n126.pdf>. Acesso em 19 jan 2011

VIEIRA, A. L. da C. Política de educação, educação como política: observações sobre a ação afirmativa como estratégia política. In: Educação e ações afirmativas: entre a injustiça simbólica e a justiça econômica. Brasília: INEP, 2003. p. 83-97.

WALTERS, R. Racismo e ação afirmativa. In: Multiculturalismo e racismo: o papel da ação afirmativa nos estados democráticos contemporâneos. Brasília: Ministério da Justiça, 1996. p. 105-121.

VYGOTSKY, L. S; LURIA, A R. Estudos sobre a história do comportamento: o macaco, o primitivo e a criança. Porto Alegre: Artes Médicas, 1996.

VYGOTSKY, L. S. Fundamentos da Defectologia: Obras Completas. Cuba: Editorial Pueblo y Educación, 1997.

VYGOTSKY, L. S. A formação social da mente: o desenvolvimento dos processos psicológicos superiores. São Paulo: Martins Fontes, 6ª ed., 1998.

VYGOTSKY, L. S. Pensamento e Linguagem. São Paulo: Martins Fontes, $2^{a}$ ed., 1999

VYGOTSKY, L. S. Manuscrito de 1929. In: Revista quadrimestralda ciência e da educação. Educação e Sociedade. n. 71. a XXI. Campinas, Unicamp, out. 2001. 
APÊNDICES 
Apêndice A - Questionário 1 (Entrevista com profissionais da escola)

\section{QUESTIONÁRIO AOS PROFISSIONAIS DA REDE PÚBLICA DA EDUCAÇÃO}

1-Você trabalha há quanto tempo na rede Municipal de ensino de Ipatinga?
a-( ) menos de 5 anos
b-( ) mais de 5 anos
c-( ) mais de 10 anos
d- ( ) mais de 15 anos.

2-Você professor da rede municipal de Ipatinga se sente preparado para atender alunos portadores de necessidades especiais?
a-( ) $\operatorname{sim}$
b-( ) não
c-( ) parcialmente

Justifique

3- Existe alguma dificuldade em incluir os alunos portadores de deficiência, nas atividades propostas durante as aulas?
a-( ) $\operatorname{sim}$
b-( )não

Justifique

4-Nesta escola é disponibilizada serviços de apoio à criança portadora de deficiência?
a-( ) $\operatorname{sim}$
b- ( ) não

Que tipo?

5- Você tem conhecimento do que rege o PPP sobre o atendimento de alunos com deficiências? a- ( ) sim b-( ) não

6-Como os demais alunos da sala receberam e interagem com os alunos portadores de deficiência? Descreva.

7- A rede municipal oferece capacitação para ajudar no atendimento desses alunos NEE?
a- ( ) $\operatorname{sim}$
b-( ) não

Assinatura:

Obrigada pela participação!

(Adaptado de pesquisas diversas e conforme o objetivo proposto pelo presente estudo 
Apêndice B - Questionário 2 (Entrevista com a família)

\section{RELATO DA FAMÍLIA SOBRE O EDUCANDO COM NEE}

1- Como foi que você descobriu que seu filho(a) era portadora de NEE? Como se sentiu? Que providências tomou?

2- O que você espera que a escola faça por seu filho no decorrer do tempo em que ele nela permanecer?

3- Há outras dificuldades que a família enfrenta em decorrência da limitação do(os) filho(os)? Quais? 
Apêndice C - Questionário 3 (Entrevista com os alunos)

\section{PESQUISA COM ALUNOS DA REDE PÚBLICA DE IPATINGA COM NEE}

1- Quais as pessoas de sua família com as quais você convive no seu dia-a-dia?

2- Nos lugares onde você freqüenta diferente da escola, quais as pessoas que mais você gosta de se relacionar? E por quê ?

3- Numere em ordem de importância para você os ambientes abaixo relacionados

( ) Igreja ( ) escola ( ) casa ( ) clube ( ) parque

4- O que você acha da escola onde você estuda?

5- O que você mais gosta na escola?

6- E o que menos gosta?

7- Qual seu maior sonho?

8- O que você acha dos seus colegas?

9- Deixe uma mensagem para alguém que você goste ou desenhe algo para ele(a). 
ANEXOS 
Anexo A - Carta de apresentação à instituição

Universidade de Brasília - UnB
Instituto de Psicologia - IP
Programa de Pós-Graduação em Processos de Desenvolvimento Humano e Saúde PG-PDS
Curso de Especialização em Desenvolvimento Humano, Educação e Inclusão Escolar

\section{CARTA DE APRESENTAÇÃO À ESCOLA}

A(o) Diretor(a): Sônia Maria Costa Ramos

Escola Municipal Deolinda Tavares Lamego

De: Profa. Dra. Diva Albuquerque Maciel - Coordenadora Geral do Curso de Especialização em Desenvolvimento Humano, Educação e Inclusão Escolar

Assunto: Coleta de Dados para Monografia

Senhor (a), Diretor (a),

A Universidade Aberta do Brasil - Universidade de Brasília está em processo de realização da $1^{\underline{a}}$ oferta do curso de Especialização em Desenvolvimento Humano, Educação e Inclusão Escolar.

Finalizamos agora a $1^{\underline{a}}$ fase do curso e estamos iniciando a Orientação de Monografia.

É requisito parcial para a conclusão do curso, a realização de um estudo empírico sobre tema acerca da inclusão no contexto escolar, cujas estratégias metodólgicas podem envolver: entrevista com colegas, pais ou outros participantes; observação; e análise documental.

A realização desses trabalhos tem como objetivo a formação continuada dos professores/servidores, subsidiando-os no desenvolvimento de uma prática pedagógica refletida e transformadora, tendo como conseqüência uma educação inclusiva.

O trabalho será realizado pelo professor/cursista: Vera Lúcia Roque Santos sob orientação Professora: Anelice da Silva Batista cujo tema é: A socialização de alunos com deficiência intelectual na escola possa ser desenvolvido na escola sob sua direção.

Desde já agradeço, colocando-me a disposição de Vossa Senhoria para maiores esclarecimentos.

Atenciosamente, 
Anexo B - Termo de Consentimento Livre e Esclarecido

\author{
Universidade de Brasília - UnB \\ Instituto de Psicologia - IP \\ Programa de Pós-Graduação em Processos de Desenvolvimento Humano e Saúde PG-PDS \\ Curso de Especialização em Desenvolvimento Humano, Educação e Inclusão Escolar
}

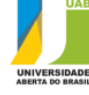

\title{
TERMO DE CONSENTIMENTO LIVRE E ESCLARECIDO
}

Senhores Professores,

Sou orientando do Curso de Especialização em Desenvolvimento Humano, Educação e Inclusão Escolar, realizado pelo Instituto de Psicologia por meio da Universidade Aberta do Brasil- Universidade de Brasília (UAB-UnB) e estou realizando um estudo sobre A socialização de alunos com deficiência intelectual na escola .Este estudo poderá fornecer às instituições de ensino subsídios para o planejamento de atividades com vistas à promoção de condições favoráveis ao pleno desenvolvimento dos alunos em contextos inclusivos e, ainda, favorecer o processo de formação continuada dos professores nesse contexto de ensino.

Constam da pesquisa (gravações em vídeo das situações cotidianas e rotineiras da escola, próprias das NEEs, ainda, entrevistas (gravadas em áudio) com os professores no intuito de mostrar a forma de socialização dos mesmos na rotina diária da escola). Para isso, solicito sua autorização para participação no estudo.

Esclareço que a participação no estudo é voluntária. Você poderá deixar a pesquisa a qualquer momento que desejar e isso não acarretará qualquer prejuízo a você. AsseguroIhe que sua identificação não será divulgada em hipótese alguma e que os dados obtidos serão mantidos em total sigilo, sendo analisados coletivamente.

Caso tenha alguma dúvida sobre o estudo, o (a) senhor(a) poderá me contatar pelo telefone 38298368 ou no endereço eletrônico vroquesantos@yahoo.com.br. Se tiver interesse em conhecer os resultados desta pesquisa, por favor, indique um e-mail de contato.

Agradeço antecipadamente sua atenção e colaboração.

Respeitosamente,

Orientanda do UAB - UnB

Concorda em participar do estudo? ( ) Sim ( ) Não

Concorda com a gravação de áudio? ( ) Sim ( ) Não 


\title{
Anexo C - Resolução Sobre a Educação de Alunos com NEE
}

\author{
Universidade de Brasília - UnB \\ Instituto de Psicologia - IP \\ Programa de Pós-Graduação em Processos de Desenvolvimento Humano e Saúde PG-PDS \\ Curso de Especialização em Desenvolvimento Humano, Educação e Inclusão Escolar
}

\section{RESOLUÇÃO SOBRE A EDUCAÇÃO DE ALUNOS COM NEE EM MG}

Resolução SE 11, de 31-1-2008

Dispõe sobre a educação escolar de alunos com necessidades educacionais especiais nas escolas da rede estadual de ensino e dá providências correlatas.

A Secretária da Educação, com fundamento no disposto nas Constituições Federal e Estadual, na Lei de Diretrizes e Bases da Educação Nacional, no Estatuto da Criança e do Adolescente e na Indicação n 70/07 e Deliberação nº 68/07 do Conselho Estadual de Educação, e considerando que:

0 atendimento escolar de alunos que apresentam necessidades educacionais especiais farse-á preferencialmente, em classes comuns da rede regular de ensino, com apoio de serviços especializados organizados na própria ou em outra unidade escolar, ou, ainda, em centros de apoio regionais;

a inclusão, permanência, progressão e sucesso escolar de alunos com necessidades educacionais especiais em classes comuns do ensino regular representam a alternativa mais eficaz no processo de atendimento desse alunado;

os paradigmas atuais da inclusão escolar vêm exigindo a ampliação dos serviços de apoio especializado e a adoção de projetos pedagógicos e metodologias de trabalho inovadores,

Resolve:

Art. $1^{\circ}$ - São considerados alunos com necessidades educacionais especiais:

I - alunos com deficiência física, mental, sensorial e múltipla, que demandem atendimento educacional especializado;

II - alunos com altas habilidades, superdotação e grande facilidade de aprendizagem, que os levem a dominar, rapidamente, conceitos, procedimentos e atitudes;

III - alunos com transtornos invasivos de desenvolvimento;

IV - alunos com outras dificuldades ou limitações acentuadas no processo de desenvolvimento, que dificultam o acompanhamento das atividades curriculares e necessitam de recursos pedagógicos adicionais.

Art. $2^{\circ}$ - Os alunos com necessidades educacionais especiais, ingressantes na $1^{\text {a }}$ série do ensino fundamental ou que venham transferidos para qualquer série ou etapa do ensino fundamental e médio, serão matriculados, preferencialmente, em classes comuns do ensino 
regular, excetuando-se os casos, cuja situação específica, não permita sua inclusão direta nessas classes.

$\S 1^{\circ}$ - O encaminhamento dos alunos de que trata o caput deste artigo para serviços de apoio pedagógico especializado em salas de recursos far-se-á somente após avaliação pedagógica realizada em conformidade com o disposto na presente resolução.

$\S 2^{\circ}$ - Aplicam-se aos alunos da modalidade de educação especial, as mesmas regras previstas no regimento da escola para fins de classificação em qualquer série ou etapa, independente de escolarização anterior, mediante avaliação realizada pela escola.

Art. 3 - O atendimento escolar a ser oferecido ao aluno com necessidades educacionais especiais, deverá ser orientado por avaliação pedagógica realizada pela equipe da escola, formada pelo Diretor, Professor Coordenador e Professor da sala comum, podendo, ainda, contar, com relação aos aspectos físicos, motores, visuais, auditivos e psico-sociais, com o apoio de professor especializado da Diretoria de Ensino e de profissionais da área da saúde. Art. 4ํ- - Caberá aos Conselhos de Classe/Ciclo/Série/Termo, ao final de cada ano letivo, aprovar relatório circunstanciado de avaliação, elaborado por professor da área, contendo parecer conclusivo sobre a situação escolar dos alunos atendidos pelos diferentes serviços de apoio especializado, acompanhado das fichas de observação periódica e contínua, em conformidade com os Anexos I, II e III desta resolução.

Art. 5 - Os alunos com deficiências que apresentem severo grau de comprometimento, cujas necessidades de recursos e apoios extrapolem, comprovadamente, as disponibilidades da escola, deverão ser encaminhados às respectivas instituições especializadas conveniadas com a Secretaria da Educação.

Art. 6으 - em se tratando de alunos com significativa defasagem idade/série e severa deficiência mental ou grave deficiência múltipla, que não puderem atingir os parâmetros exigidos para a conclusão do ensino fundamental, as escolas poderão, com fundamento no inciso II do artigo 59 da Lei 9.394/96, expedir declaração com terminalidade específica de determinada série, acompanhada de histórico escolar e da ficha de observação contendo, de forma descritiva, as competências desenvolvidas pelo educando.

$\S 1$ 으 - A terminalidade prevista no caput deste artigo somente poderá ocorrer em casos plenamente justificados mediante relatório de avaliação pedagógica, balizada por profissionais da área da saúde, com parecer aprovado pelo Conselho de Escola e visado pelo Supervisor de Ensino.

$\S 2^{0}$ - A escola deverá articular-se com os órgãos oficiais ou com as instituições que mantenham parcerias com o Poder Público, a fim de fornecer orientação às famílias no encaminhamento dos alunos a programas especiais, voltados para o trabalho, para sua efetiva integração na sociedade. 
Art. $7^{0}$ - Consideradas as especificidades regionais e locais, serão organizados, gradativamente, em nível de unidade escolar e por sua solicitação, Serviços de Apoio Pedagógico Especializado (SAPEs), desde que acompanhados dos termos de anuência da Diretoria de Ensino e da respectiva Coordenadoria de Ensino.

Art. 8o - A implementação de Serviços de Apoio Pedagógico Especializado (SAPEs) tem por objetivo melhorar a qualidade da oferta da educação especial, na rede estadual de ensino, viabilizando-a por uma reorganização que, favorecendo a adoção de novas metodologias de trabalho, leve à inclusão do aluno em classes comuns do ensino regular.

Parágrafo único - Os Serviços de Apoio Pedagógico Especializado (SAPEs) serão implementados por meio de:

1 - atendimento prestado por professor especializado, em sala de recursos específicos, em horários programados de acordo com as necessidades dos alunos, e, em período diverso daquele que o aluno freqüenta na classe comum, da própria escola ou de outra unidade;

2 - atendimento prestado por professor especializado, na forma de itinerância.

Art. 9- - Os alunos que não puderem ser incluídos em classes comuns, em decorrência de severa deficiência mental ou grave deficiência múltipla, ou mesmo apresentarem comprometimento do aproveitamento escolar em razão de transtorno invasivo do desenvolvimento, poderão contar, na escola regular, em caráter de excepcionalidade e transitoriedade, com o atendimento em classe regida por professor especializado, observado o disposto no parágrafo único do art. $4^{\circ}$ da Deliberação CEE 68/07.

$\S 1^{0}$ - Esgotados os recursos pedagógicos necessários para manutenção do aluno em classe regular, a indicação da necessidade de atendimento em classe regida por professor especializado deverá resultar de uma avaliação multidisciplinar, a ser realizada por equipe de profissionais indicados pela escola e pela família.

$\S 2^{\circ}$ - O tempo de permanência do aluno na classe regida por professor especializado dependerá da avaliação multidisciplinar e de avaliações periódicas a serem realizadas pela escola, com participação dos pais e do Conselho de Escola e/ou estrutura similar, com vistas a sua inclusão em classe comum.

§ 3ํ - O caráter de excepcionalidade, de que se revestem a indicação do encaminhamento dos alunos e o tempo de sua permanência em classe regida por professor especializado, será assegurado por instrumentos e registros próprios, sob a supervisão do órgão competente.

Art. 10 - na organização dos Serviços de Apoio Especializado (Sapes) nas Unidades Escolares, observar-se-á que:

I - o funcionamento da sala de recursos será de 16 (dezesseis ) aulas semanais, distribuídas de acordo com a demanda do alunado, com turmas constituídas de 10 a 15 
alunos, de modo a atender alunos de 02(dois) ou mais turnos, quer individualmente, quer em pequenos grupos na conformidade das necessidades do(s) aluno(s);

II - as aulas do atendimento itinerante, a serem atribuídas ao docente titular de cargo como carga suplementar e ao ocupante de função-atividade na composição da respectiva carga horária, serão desenvolvidas em atividades de apoio ao aluno com necessidades especiais, em trabalho articulado com os demais profissionais da escola;

III - o apoio oferecido aos alunos, em sala de recursos ou no atendimento itinerante, terá como parâmetro o desenvolvimento de atividades que não deverão ultrapassar a 2 aulas diárias.

Art. 11 - a organização dos SAPEs na unidade escolar, sob a forma de sala de recursos, somente poderá ocorrer quando houver:

I - comprovação de demanda avaliada pedagogicamente;

Il-professor habilitado ou, na ausência deste, professor com Licenciatura Plena em Pedagogia e curso de especialização na respectiva área da necessidade educacional, com, no mínimo, 360 horas de duração;

III- espaço físico adequado, não segregado;

IV- recursos e materiais didáticos específicos;

$\mathrm{V}$ - parecer favorável da CENP, expedido pelo Centro de Apoio Pedagógico Especializado.

$\S 1^{\circ}$ - As turmas a serem atendidas pelas salas de recursos poderão ser instaladas para atendimento de alunos de qualquer série, etapa ou modalidade do ensino fundamental ou médio, e as classes com professor especializado, somente poderão atender alunos cujo grau de desenvolvimento seja equivalente ao previsto para o Ciclo I.

$\S 2^{\circ}$ - A constituição da turma da sala de recursos, da classe com professor especializado e da itinerância deverá observar o atendimento a alunos de uma única área de necessidade educacional especial.

Art. 12 - Os docentes, para atuarem nos SAPEs, deverão ter formação na área da necessidade educacional especial, observada a prioridade conferida ao docente habilitado.

Art. 13- Caberá ao professor de Educação Especial, além do atendimento prestado ao aluno:

I - participar da elaboração da proposta pedagógica da escola;

II - elaborar plano de trabalho que contemple as especificidades da demanda existente na unidade e/ou na região, atendidas as novas diretrizes da Educação Especial;

III- integrar os conselhos de classes/ciclos/séries/termos e participar das HTPCs e/ou outras atividades coletivas programadas pela escola;

IV- orientar a equipe escolar quanto aos procedimentos e estratégias de inclusão dos alunos nas classes comuns;

$\mathrm{V}$ - oferecer apoio técnico pedagógico aos professores das classes comuns; 
$\mathrm{VI}$ - fornecer orientações e prestar atendimento aos responsáveis pelos alunos bem como à comunidade.

Art. 14 - As unidades escolares que não comportarem a existência dos SAPEs poderão, definida a demanda, contar com o atendimento itinerante a ser realizado por professores especializados alocados em SAPEs ou escolas da região, atendidas as exigências previstas no art. 17 da Resolução SE 90/05.

Art. 15 - Caberá às Diretorias de Ensino:

I - proceder ao levantamento da demanda das salas de recursos e do apoio itinerante, visando à otimização e à racionalização do atendimento com o objetivo de transformar ou transferir o serviço oferecido, remanejando os recursos e os equipamentos para salas de unidades escolares sob sua jurisdição;

II- propor a criação de serviços de apoio pedagógico especializado à respectiva Coordenadoria de Ensino;

III- orientar e manter as escolas informadas sobre os serviços ou instituições especializadas existentes na região, mantendo contatos com as mesmas, de forma a agilizar o atendimento de alunos.

Art. 16 - As situações não previstas na presente resolução serão analisadas e encaminhadas por um Grupo de Trabalho constituído por representantes da CENP/CAPE, Cogsp e/ou CEI e Diretoria(as) de Ensino envolvida(s).

Art. 17 - Esta resolução entra em vigor na data de sua publicação, ficando revogadas as disposições em contrário, em especial, a Resolução SE 95/00.

Publicada no Diário Oficial em 1ํ de fevereiro de 2008 